\title{
Imbrium provenance for the Apollo 16 Descartes terrain: Argon ages and geochemistry of lunar breccias 67016 and 67455
}

\author{
M.D. Norman ${ }^{\mathrm{a}, \mathrm{b}, *}$, R.A. Duncan ${ }^{\mathrm{c}}$, J.J. Huard ${ }^{\mathrm{c}}$ \\ ${ }^{a}$ Research School of Earth Sciences, Australian National University, Canberra 0200, Australia \\ ${ }^{\mathrm{b}}$ Lunar and Planetary Institute, 3600 Bay Area Boulevard, Houston TX 77058, USA \\ ${ }^{\mathrm{c}}$ College of Oceanic and Atmospheric Sciences, Oregon State University, Corvallis, OR 97331, USA
}

Received 23 January 2009; accepted in revised form 16 September 2009; available online 21 October 2009

\begin{abstract}
In order to improve our understanding of impact history and surface geology on the Moon, we obtained ${ }^{40} \mathrm{Ar}-{ }^{39} \mathrm{Ar}$ incremental heating age data and major + trace element compositions of anorthositic and melt breccia clasts from Apollo 16 feldspathic fragmental breccias 67016 and 67455. These breccias represent the Descartes terrain, a regional unit often proposed to be ejecta from the nearby Nectaris basin. The goal of this work is to better constrain the emplacement age and provenance of the Descartes breccias.

Four anorthositic clasts from 67016 yielded well-defined ${ }^{40} \mathrm{Ar}-{ }^{39} \mathrm{Ar}$ plateau ages ranging from $3842 \pm 19$ to $3875 \pm 20 \mathrm{Ma}$. Replicate analyses of these clasts all agree within measurement error, with only slight evidence for either inheritance or younger disturbance. In contrast, fragment-laden melt breccia clasts from 67016 yielded apparent plateau ages of 4.0-4.2 Ga with indications of even older material (to $4.5 \mathrm{Ga}$ ) in the high-T fractions. Argon release spectra of the 67455 clasts are more variable with evidence for reheating at 2.0-2.5 Ga. We obtained plateau ages of $3801 \pm 29$ to $4012 \pm 21$ Ma for three anorthositic clasts, and $3987 \pm 21 \mathrm{Ma}$ for one melt breccia clast. The anorthositic clasts from these breccias and fragments extracted from North Ray crater regolith (Maurer et al., 1978) define a combined age of $3866 \pm 9 \mathrm{Ma}$, which we interpret as the assembly age of the feldspathic fragmental breccia unit sampled at North Ray crater. Systematic variations in diagnostic trace element ratios $(\mathrm{Sr} / \mathrm{Ba}, \mathrm{Ti} / \mathrm{Sm}, \mathrm{Sc} / \mathrm{Sm})$ with incompatible element abundances show that ferroan anorthositic rocks and KREEP-bearing lithologies contributed to the clast population.

The Descartes breccias likely were deposited as a coherent lithologic unit in a single event. Their regional distribution suggests emplacement as basin ejecta. An assembly age of $3866 \pm 9$ Ma would be identical with the accepted age of the Imbrium basin, and trace element compositions are consistent with a provenance in the Procellarum-KREEP Terrane. The combination of age and provenance constraints points toward deposition of the Descartes breccias as ejecta from the Imbrium basin rather than Nectaris. Diffusion modeling shows that the older apparent plateau ages of the melt brecia clasts plausibly result from incomplete degassing of ancient crust during emplacement of the Descartes breccias. Heating steps in the melt breccia clasts that approach the primary crystallization ages of lunar anorthosites show that earlier impact events did not completely outgas the upper crust.
\end{abstract}

(C) 2009 Elsevier Ltd. All rights reserved.

\section{INTRODUCTION}

${ }^{*}$ Corresponding author. Address: Research School of Earth Sciences, Australian National University, Canberra, AU 0200, Australia. Tel.: +61 25 4373; fax: +61 254835 .

E-mail addresses: marc.norman@anu.edu.au (M.D. Norman), rduncan@coas.oregonstate.edu (R.A. Duncan), huard@coas. oregonstate.edu (J.J. Huard).
The primary geological objective of the Apollo 16 mission to the Moon was to investigate and sample two physiographic units identified by pre-mission planning: the "Descartes Mountains" and the "Cayley Plains" (Muehlberger et al., 1980). Both units were found to be 
impact-related deposits, distinguished by differences in lithology and bulk composition as well as morphology (Stöffler et al., 1981, 1985), but the provenance and genetic relationship of these units to specific basins or craters is not well established. The Descartes breccias are of particular interest because they are often considered to be primary ejecta from the Nectaris basin (Stöffler et al., 1981, 1985; Stöffler and Ryder, 2001). Existing constraints on the source of the Descartes breccias are, however, permissive and subject to interpretation. Arguments for an origin as Nectaris ejecta are based mainly on analogues with the Orientale basin, the youngest and best-preserved multi-ring basin on the Moon (Head, 1974), and predictions from cratering models (James, 1981). Alternatively, geological relationships observed from lunar orbit suggest that the Descartes and Cayley units both could be distal ejecta from the Imbrium basin (Hodges et al., 1973; Ulrich, 1973).

As Nectaris ejecta, the emplacement age of these breccias would have significant implications for lunar stratigraphy and the hypothesis that the Moon experienced a late heavy bombardment of impacting planetesimals at about $4 \mathrm{Ga}$. Nectaris is the one of oldest nearside basins and together with Imbrium stratigraphically brackets 12 other lunar basins. The often-quoted ages of $3.92 \mathrm{Ga}$ for Nectaris and 3.85 Ga for Imbrium (Stöffler and Ryder, 2001) tend to favor a late heavy bombardment, whereas an older age of Nectaris would weaken the case for a late cataclysm (Bottke et al., 2007; Norman and Lineweaver, 2008; Norman, 2009). Geochemical characteristics of the Descartes breccias are similar to those of the Feldspathic Highlands Terrane (Jolliff et al., 2000), so a better understanding of these breccias may provide insights into the origin and evolution of major crustal provinces on the Moon as well as the early impact history of the inner solar system.

The goal of this study is to improve constraints on the provenance and emplacement age of the Descartes breccias. We report ${ }^{40} \mathrm{Ar}-{ }^{39} \mathrm{Ar}$ incremental heating ages, major element, and trace element compositions of representative clasts extracted from two feldspathic fragmental breccias that were collected from the rim of North Ray crater (67016, 67455). Anorthositic clasts with well-behaved ${ }^{40} \mathrm{Ar}-{ }^{39} \mathrm{Ar}$ spectra define ages that are identical with the currently accepted age of the Imbrium basin, and trace element compositions suggest a provenance in the Procellarum-KREEP Terrane. We argue that these characteristics points toward emplacement of the Descartes breccias as Imbrium ejecta, and briefly discuss implications of this conclusion for assignment of basin ages and the late heavy bombardment hypothesis.

\section{SAMPLES AND PREVIOUS WORK}

67016 and 67455 are typical Apollo 16 feldspathic fragmental breccias (nomenclature of Stöffler et al., 1980 and James, 1981). They comprise lithic clasts of dark, fragment-laden melt breccia and a diverse array of crystalline anorthositic lithologies that include ferroan, magnesian, and sodic varieties in a lightly welded matrix of mineral fragments. The melt breccia clasts are composed of 80-90 vol $\%$ angular fragments of plagioclase in a finely-crystal- line, rapidly quenched melt matrix consisting of intergrown plagioclase and pyroxene (Nord et al., 1975; Minkin et al., 1977; Norman, 1981; Stöffler et al., 1985). Rounded blebs of metallic iron, troilite, and schreibersite are common whereas clastic fragments of olivine or pyroxene are rare. Anorthositic clasts in these two breccias sample ancient crustal lithologies, including (meta)igneous ferroan anorthosite and noritic anorthosite, and more magnesian noritic to troctolitic impactites with granoblastic to poikiloblastic textures (Minkin et al., 1977; Norman, 1981; Stöffler et al., 1985). The primary crystallization age of the igneous ferroan noritic anorthosite lithology is inferred to be $\sim 4.45$ Ga (Norman et al., 2003) whereas at least some of the magnesian impactites may have formed at about $4.2 \mathrm{Ga}$ by analogy with a similar lithology sampled as 67955 (Norman et al., 2007).

67016 is a moderately coherent rock that was collected as a discrete sample from the SE rim of North Ray crater. Norman (1981) described the petrography of 67016 including a detailed documentation of the lithic clast population; additional studies of the petrology and geochemistry of the unusual ferroan noritic anorthosite and sodic anorthosite clast lithologies are given by Norman et al. (1991, 1995). Lindstrom and Salpas (1981, 1983) and Norman and Taylor (1992) conducted geochemical studies of clasts and whole rock splits of this breccia, and Alibert et al. (1994) determined a ${ }^{147} \mathrm{Sm}-{ }^{143} \mathrm{Nd}$ mineral isochron age and $\mathrm{Sr}$ isotopic compositions of a ferroan noritic anorthosite clast. Turner and Cadogan (1975) present ${ }^{40} \mathrm{Ar}-{ }^{39} \mathrm{Ar}$ data for three samples of 67016 (white powdery matrix, dark clast, coarse plagioclase). The white powdery matrix yielded a complex release pattern with an intermediate maximum at $3.95 \pm 0.03 \mathrm{Ga}$ and a total argon age of $3.82 \mathrm{Ga}$. (All argon ages discussed here have been recalculated to decay constants of Steiger and Jäger, 1977). The dark clast and coarse plagioclase splits gave identical ages of $3.89 \pm 0.05$ and $3.89 \pm 0.07 \mathrm{Ga}$, respectively.

67455 was chipped from a large white boulder on the south rim of North Ray crater. It is very friable and the clasts tend to show greater levels of shock compared with lithologically similar clasts in 67016. Minkin et al. (1977) described the petrography, mineral chemistry, and major element compositions of lithic clasts in 67455. Lindstrom et al. (1977) and Lindstrom and Salpas (1981) report major and trace element data for individual clasts. A single ${ }^{40} \mathrm{Ar}-{ }^{39} \mathrm{Ar}$ determination for an anorthositic clast produced scattered heating steps from 3.35-4.54 Ga without a plateau age (Schaeffer and Schaeffer, 1977).

Samples analyzed for this study included eight different clasts of dark melt breccia and 4 anorthositic clasts from 67016, plus three anorthositic clasts and one dark melt breccia clast from 67455 . Based on a binocular examination we tentatively classified the anorthositic clasts as 'ferroan noritic anorthosite' (67016,383 and 67455,275; pale brown pyroxenes, oxides and sulfides), 'magnesian granulite' (67016,390; fine-grained, pale green tint), and 'mafic-poor anorthosite' (67016,384, 67016,391, 67455,271 and 67455,273; white).

From examination of Lunar Sample Data Packs at NASA-JSC, all samples of 67016 analyzed for this study 
appear to have been allocated from splits of chips and fines produced during earlier processing of the breccia. Clast material was handpicked by G. Ryder. There appears to have been no prior allocations from the parent splits of these clasts except for sample 67016,383. This ferroan noritic anorthosite clast was picked from a residue of chips and fines $(, 325)$ produced during extraction of a similar clast allocated previously for geochemistry and $\mathrm{Sm}-\mathrm{Nd}$ isotopes as sample ,322 and ,324 (Norman and Taylor, 1992; Alibert et al., 1994). Clast 67016,383 analyzed here is likely, but not definitively, the same material as ,322 and ,324 (,323 is a polished thin section of this clast). The 67455 clasts were picked by G. Ryder out of $>2 \mathrm{~mm}$ sieved coarse particle splits prepared by E.C.T. Chao during processing of the breccia in the NASA-JSC Lunar Curatorial Lab. The parent splits for the anorthositic particles analyzed here nominally represent shocked, sheared, or granulated cataclastic anorthosites, with (,35 parent to ,271) or without (,36 parent to ,273) visible mafics, and coherent, crystalline, recrystallized anorthositic to troctolitic or noritic "hornfels" (,40 parent to ,275; Data Pack processing notes by E.C.T. Chao recorded in 1974, based on binocular microscope examination in the Lunar Curatorial Lab). A photograph of these splits is shown in Minkin et al. (1977). The melt breccia clast $(, 277)$ was extracted by Ryder from a split of chips and fines.

Maurer et al. (1978) conducted the most comprehensive previous argon dating study on material most directly analogous to the clasts studied here. They present incremental heating ages, REE abundances and partial major element data for a diverse suite of fragments separated from three samples of regolith collected at Stations 11 and 13 (63503, 67603,67703 ). Relatively large samples (9-75 mg, typically $15-30 \mathrm{mg}$ ) were used for that study. Three groups were recognized based on apparent clusterings of the plateau ages: an older Group 1 with ages of 4.1-4.2 Ga, an intermediate Group 2 with ages of 3.83-3.96 Ga, and a younger group with ages $<2.5 \mathrm{Ga}$. A significant fraction of their samples (18 of 48 fragments) were considered to be 'non-datable' due to complex age curves or large corrections for trapped ${ }^{40} \mathrm{Ar}$. Schaeffer and Husain (1973) present ${ }^{40} \mathrm{Ar}-{ }^{39} \mathrm{Ar}$ data for 6 fragments of anorthosite and melt breccia from North Ray crater regolith sample 67483. Plateau ages of these fragments range from 4.0 to $4.2 \mathrm{Ga}$.

\section{METHODS}

${ }^{40} \mathrm{Ar}-{ }^{39} \mathrm{Ar}$ incremental heating age determinations were conducted on 28 samples representing 12 clasts from 67016 and 4 clasts from 67455 following procedures similar to those used by our previous study of Apollo 16 melt breccias (Norman et al., 2006). We encapsulated 0.8 to $3.7 \mathrm{mg}$ of clast material in evacuated quartz vials and had them irradiated for $300 \mathrm{~h}$ in the OSU experimental TRIGA reactor. Neutron fluence was monitored with Mmhb-1 hornblende (513.9 Ma; Lanphere et al., 1990). This monitor age was used in order to compare these data directly with age determinations by Dalrymple and Ryder (1993, 1996) and Norman et al. (2006). More recent intercalibrations place the age of Mmhb-1 at 521-523 Ma (Baksi et al.,
1996; Renne et al., 1998). Using the older monitor age would increase the ages reported here by $1.4-1.8 \%$. The neutron capture efficiency factor $J$ for each lunar sample was calculated from 4 total fusion measurements of 5 to 6 grains each of the monitor mineral irradiated at the same positions as the unknowns. The precision in $J$ is $<0.5 \%$, based on the regression of multiple measurements against vertical position.

We heated samples with a $10 \mathrm{~W}$ continuous power $\mathrm{CO}_{2}$ laser in 20-35 temperature increments (heating steps). The small size $(\leqslant 4 \mathrm{mg})$ of the samples helped avoid mixed clast compositions, the large number of steps allowed better determination of the structure of the gas release, and the large number of samples provided a useful set of internally consistent age data for a range of clast compositions. Ages calculated from the released gas at these heating steps formed "plateaus" comprising $30-100 \%$ of the total. Plateau ages are the mean of three or more concordant, contiguous step ages (weighted by inverse of variance). The mean square of weighted deviations (MSWD) is an $F$-statistic that compares the variability of step ages about the mean with the individual step variances, for those steps that comprise a proposed plateau. A value less than about 2.5 indicates that the step ages are true samples of a common plateau age (York, 1969). We calculated an isochron age from the slope of the linear regression of ${ }^{40} \mathrm{Ar} /{ }^{36} \mathrm{Ar}$ vs ${ }^{39} \mathrm{Ar} /{ }^{36} \mathrm{Ar}$ compositions for the same steps that comprise the plateau age. In all experiments, plateau and isochron ages were concordant, within analytical error. For experiments in which step ages met the MSWD criteria (and plateau and isochron ages agree), we concluded that the plateau age is statistically significant and robust. We prefer to use the plateau ages, rather than the isochron ages for comparison because they generally have lower analytical uncertainties, in keeping with previous work (Norman et al., 2006). We also calculated $\mathrm{K} / \mathrm{Ca}$ for each step from measured ${ }^{39} \mathrm{Ar}$ (generated by neutron reactions with ${ }^{39} \mathrm{~K}$ ) and ${ }^{37} \mathrm{Ar}$ (generated from neutron reactions with ${ }^{40} \mathrm{Ca}$ ), as an indication of the phase(s) contributing to gas release.

Corrections for interfering $\mathrm{Ar}$ isotopes produced by undesirable reactions with $\mathrm{Ca}$ and $\mathrm{K}$ for the OSU TRIGA reactor were those determined previously (Renne et al., 1998; Koppers et al., 2003). The corrections for trapped Ar isotopes are the solar values, while those for cosmogenic Ar isotopes are from Hohenberg et al. (1978); atmospheric $\mathrm{Ar}$ is assumed to be negligible. The measured Ar isotopes were corrected for the system background using the results of blank measurements made at the beginning of each day and after every four or five unknown sample temperature steps, and are generally $1-2 \%$ of step gas concentrations for $m / e=37,38,39$ and 40 , and $<4 \%$ for $m / e=36$. All of the corrections are known with sufficient precision that they contribute negligible error to the age calculations for the lunar samples we analyzed. Uncertainties $(2 \sigma)$ for individual ages are typically 20-40 Ma.

Major and trace element compositions were measured by solution aspiration ICPMS on whole rock powders prepared from separate splits of 11 of the clasts (powders not available for the other 5 clasts). Approximately $30 \mathrm{mg}$ samples were used for these analyses, except for 67016,385 
$(3.87 \mathrm{mg})$ and $67016,392(7.03 \mathrm{mg})$ for which only a small amount of material was available. The powder was dissolved in $\mathrm{HF}-\mathrm{HNO}_{3}$ and brought to final volume in 5\% $\mathrm{HNO}_{3}$. Data were acquired using an Agilent 7500 quadrupole ICPMS at RSES. Trace elements were measured on solutions prepared to dilution factors of 1000. An additional $100 \times$ dilution was applied to aliquots of the trace element solutions for major element analysis. Each solution was spiked with $50 \mathrm{ppb}$ Be and $5 \mathrm{ppb}$ each of In, Re, and $\mathrm{Bi}$ as internal standards to correct for instrument drift during analysis. Potassium abundances were measured on the trace element solutions using a 'cool plasma' $(700 \mathrm{~W})$ to reduce the background on ${ }^{39} \mathrm{~K}$ from ${ }^{40} \mathrm{Ar}$ in the plasma. Element sensitivity was calibrated to the USGS basalt reference material BHVO-1 using major element compositions recommended by the USGS (Govindaraju, 1994) and trace element compositions of Eggins et al. (1997), Raczek et al. (2001), Robinson et al. (1999), and Pfänder et al. (2007) (Table 1). $\mathrm{SiO}_{2}$ was calculated by difference from the major element data. The USGS reference materials W-2, BCR-2, and AGV-1 were analyzed as unknowns with the samples to demonstrate accuracy and precision of the ICPMS data (Table 1). Total $\mathrm{Fe}$ is presented as $\mathrm{FeO}^{*}$.

For comparison, we also present whole rock major and trace element data for a suite of Apollo 16 whole rock impact melt breccias representing the range of major and trace element compositions of melt breccias at this site. These data were collected using methods identical to those described above. Solutions were prepared from 30 to $50 \mathrm{mg}$ splits of powders produced by hand grinding of $3 \mathrm{~g}$ allocations with an agate mortar and pestle.

\section{RESULTS}

\subsection{Major and trace elements}

Major element and trace element compositions of the 67016 and 67455 clasts confirm our preliminary petrographic classifications. The 'mafic-poor' anorthositic clasts 67455,271 and 67455,273 have high $\mathrm{Al}_{2} \mathrm{O}_{3}$ (33.2-33.5 $\mathrm{wt} \%)$ and low contents of $\mathrm{FeO}(0.6-1.3 \mathrm{wt} \%), \mathrm{MgO}(0.4$ $1.4 \mathrm{wt} \%)$, Ni (3-10 ppm) and incompatible lithophile trace elements that are similar to pristine ferroan anorthosites (Table 2 and Figs. 1 and 2). Anorthositic clast 67455,275 contained visible enrichment of pyroxene, which is reflected in its lower $\mathrm{Al}_{2} \mathrm{O}_{3}(29.0 \mathrm{wt} \%)$ and higher $\mathrm{FeO}(5.5 \mathrm{wt} \%)$, $\mathrm{MgO}(4.2 \mathrm{wt} \%), \mathrm{Ti}, \mathrm{Sc}, \mathrm{V}$, and $\mathrm{Cr}$ compared to 67455,271 and ,273 (Table 2 and Fig. 1). The ferroan $(\mathrm{Mg \#}=58)$ bulk composition and low abundances of $\mathrm{Ni}$ and incompatible trace elements in this clast also suggest affinities with pristine ferroan anorthosites. Anorthositic clast 67016,384 has an unusually sodic composition with anomalously high $\mathrm{Sr}$ and Eu (Table 2 and Fig. 2). Clast 67016,390, classified as a granulite based on optical examination, has a more magnesian bulk composition $(\mathrm{Mg} \#=76)$ with high $\mathrm{Ni}$ (131 ppm) and elevated concentrations of REE and other incompatible elements (Table 2 and Fig. 2). Similar characteristics have been observed previously in anorthositic clasts from these breccias (Lindstrom et al., 1977; Lindstrom and Salpas, 1981; Norman et al., 1991; Norman and Taylor,
1992). Melt breccia clasts, identified by their pale to dark gray color and aphanitic texture, have a restricted range of major element $\left(\mathrm{Al}_{2} \mathrm{O}_{3}=29-30 \quad \mathrm{wt} \%\right.$; Table 2 and Fig. 1) and trace element compositions that tend to be intermediate between those of the ferroan anorthositic and magnesian granulite clasts, and cluster around the composition of the bulk breccias (Fig. 1; see also Lindstrom and Salpas, 1983; Norman and Taylor, 1992). Anorthositic clasts with low incompatible trace element contents have superchondritic $\mathrm{Sr} / \mathrm{Ba}$, and $\mathrm{Ti} / \mathrm{Sm}$, and $\mathrm{Sc} / \mathrm{Sm}$ ratios that are within the ranges observed for pristine lunar ferroan anorthosites (Fig. 2; cf. Norman and Ryder, 1980; Lindstrom et al., 1977). In contrast, melt breccia and granulite clasts have $\mathrm{Ti} / \mathrm{Sm}, \mathrm{Sr} / \mathrm{Ba}$, and $\mathrm{Sc} / \mathrm{Sm}$ ratios that decrease systematically with increasing incompatible element concentrations, trending toward the compositions of KREEP-rich Apollo 16 impact melt breccias (Fig. 2).

The whole rock suite of melt breccias analyzed for this study has $\mathrm{Al}_{2} \mathrm{O}_{3}$ contents ranging from 16.6 to $28.7 \mathrm{wt} \%$, representing much of the compositional variation of Apollo 16 melt rocks (Table 3). Incompatible lithophile element abundances are inversely correlated with $\mathrm{Al}_{2} \mathrm{O}_{3}$ contents and range from concentrations similar to those of the 67016 and 67455 granulite clasts to much higher values (e.g., $\mathrm{Nb}$ 5.7-48.2 ppm, La 6.7-59.8 ppm; Table 3). $\mathrm{Ti} / \mathrm{Sm}, \mathrm{Sr} / \mathrm{Ba}$, and $\mathrm{Sc} / \mathrm{Sm}$ ratios also vary with $\mathrm{Al}_{2} \mathrm{O}_{3}$ and incompatible element abundances, with lower values of these ratios in the more mafic, KREEP-rich breccias (Table 3 and Fig. 2).

\section{2. ${ }^{40} \mathrm{Ar}-{ }^{39} \mathrm{Ar}$ incremental heating ages}

The four anorthositic clasts from 67016 yielded well-defined plateau ages spanning a small range from 3842 to $3875 \mathrm{Ma}$ (Table 4 and Fig. 3). This includes examples of mafic-poor (inferred to be ferroan) anorthosite (,391), ferroan noritic anorthosite (,383), sodic anorthosite (,384X) and granulite (,390). Replicate analyses of these clasts all agree within analytical uncertainty, with the entire range of ages defined by the two splits of sodic anorthosite $671016,384 \mathrm{X}$ (Table 4). The age spectra indicate only slight later disturbance or older inherited components in the 67016 anorthositic clasts. Replicate analyses of 67016,383 produced plateaus with identical ages comprising 83 $100 \%$ of the total gas released, with no low temperature ${ }^{40} \mathrm{Ar}$ loss and slightly older ages at high temperature release steps (,383-C only). These slightly older age steps in ,383-C are associated with distinctly lower $\mathrm{K} / \mathrm{Ca}$, and likely reflect an inherited component. Samples 67016,390 and 67016,391 showed only slight low temperature loss $(<1 \%$ of total gas released). Sample $67016,384 \mathrm{X}$ showed more significant low temperature Ar loss (1-2\% of total gas), probably from short-lived heating events due to subsequent impacts. These later events do not appear to have affected the robust and reproducible 15-20 step plateaus that comprise $>60 \%$ of the total gas released (Fig. 3). In addition, MSWDs for both of the $67016,384 \mathrm{X}$ replicates are below 2.5 , indicating that step ages through the plateau interval do not increase systematically with heating temperature, as would be the case if the whole sample age had been lowered through bulk 
Table 1

Major element ( $\mathrm{wt} \%$ ) and trace element ( $\mathrm{ppm})$ compositions of USGS reference materials. Major element calibration and reference values from USGS certificates (http://minerals.cr.usgs.gov/ geo chem stand/powdered RM.html). Trace element calibration values for BHVO-l from Eggins et al. (1997) except Zr, Hf, Nb, Ta from Pfänder et al. (2007), Sr from Raczek et al. (2001) and Y from Robinson et al. (1999). Trace element reference values from Eggins et al. (1997; REF-1); Yu et al. (2003; REF-2), Raczek et al. (2001; REF-3), Norman et al. (1998, REF-4) adjusted to Zr, $\mathrm{Hf}, \mathrm{Nb}$, Ta calibration values. $\mathrm{SiO}_{2}$ is by difference. nd = not detected. $\mathrm{FeOt}$ is total $\mathrm{Fe}$ as $\mathrm{FeO}$.

\begin{tabular}{|c|c|c|c|c|c|c|c|c|c|c|c|c|c|c|c|c|}
\hline wt $\%$ & $\begin{array}{l}\text { BHVO-1 } \\
\text { CAL }\end{array}$ & W-2 & $\begin{array}{l}1 \mathrm{SD} \\
n=2\end{array}$ & $\%$ rsd & USGS & AGV-1 & $\begin{array}{l}1 \mathrm{SD} \\
n=2\end{array}$ & $\%$ rsd & USGS & BCR-2 & $\begin{array}{l}1 \mathrm{SD} \\
n=2\end{array}$ & $\%$ rsd & USGS & & & \\
\hline $\mathrm{SiO}_{2}$ & 50.42 & 54.41 & 0.10 & 0.2 & 53.12 & 63.49 & 0.14 & 0.2 & 60.32 & 56.83 & 0.25 & 0.4 & 55.12 & & & \\
\hline $\mathrm{TiO}_{2}$ & 2.74 & 1.06 & 0.01 & 1.0 & 1.07 & 1.01 & 0.01 & 0.6 & 1.08 & 2.31 & 0.01 & 0.6 & 2.30 & & & \\
\hline $\mathrm{Al}_{2} \mathrm{O}_{3}$ & 13.93 & 15.59 & 0.14 & 0.9 & 15.58 & 17.24 & 0.27 & 1.6 & 17.58 & 14.14 & 0.28 & 2.0 & 13.75 & & & \\
\hline $\mathrm{FeOt}$ & 11.12 & 9.70 & 0.02 & 0.2 & 9.84 & 5.95 & 0.03 & 0.6 & 6.94 & 12.79 & 0.04 & 0.3 & 12.67 & & & \\
\hline $\mathrm{MnO}$ & 0.172 & 0.168 & 0.001 & 0.6 & 0.168 & 0.095 & 0.001 & 1.1 & 0.094 & 0.205 & 0.001 & 0.6 & 0.200 & & & \\
\hline $\mathrm{MgO}$ & 7.30 & 6.43 & 0.02 & 0.4 & 6.42 & 1.51 & 0.01 & 0.9 & 1.57 & 3.73 & 0.04 & 1.1 & 3.66 & & & \\
\hline $\mathrm{CaO}$ & 11.51 & 10.88 & 0.21 & 1.9 & 10.95 & 4.92 & 0.02 & 0.3 & 5.06 & 7.40 & 0.05 & 0.7 & 7.25 & & & \\
\hline $\mathrm{Na}_{2} \mathrm{O}$ & 2.28 & 2.24 & 0.01 & 0.6 & 2.22 & 4.23 & 0.04 & 0.8 & 4.37 & 3.27 & 0.01 & 0.4 & 3.22 & & & \\
\hline $\mathrm{K}_{2} \mathrm{O}$ & 0.52 & 0.60 & 0.04 & 5.9 & 0.63 & 2.58 & 0.10 & 4.0 & 2.99 & 1.63 & 0.08 & 4.9 & 1.82 & & & \\
\hline ppm & & & $n=8$ & & REF-1 & & $n=8$ & & REF-1 & & $n=8$ & & REF-1 & REF-2 & REF-3 & REF-4 \\
\hline $\mathrm{Li}$ & 4.9 & 9.4 & 0.1 & 1.3 & 9.6 & 10.6 & 0.4 & 3.9 & 11.2 & 9.5 & 0.5 & 4.9 & 14.0 & & & 9.6 \\
\hline $\mathrm{Sc}$ & 31.8 & 36.2 & 0.6 & 1.7 & 36.2 & 11.9 & 0.5 & 3.9 & 12.6 & 33.0 & 1.0 & 3.1 & 33.0 & 32.6 & & 33.5 \\
\hline V & 321 & 266 & 3 & 1.2 & 270 & 118 & 3 & 3.1 & 126 & 415 & 10 & 2.6 & 401 & 407 & & 429 \\
\hline $\mathrm{Cr}$ & 289 & 91 & 1 & 1.4 & 92 & 8.2 & 0.4 & 4.7 & 9 & 15 & 1 & 6.6 & 9 & & & \\
\hline Co & 45 & 45 & 1 & 2.1 & 46 & 15.1 & 0.9 & 6.2 & 16 & 37 & 2 & 6.4 & 39 & 39 & & 38 \\
\hline $\mathrm{Ni}$ & 120 & 73 & 1 & 1.9 & 74 & 14.9 & 0.9 & 6.3 & 16 & 13 & 1 & 7.1 & 12 & & & 13 \\
\hline $\mathrm{Cu}$ & 136 & 104 & 2 & 1.5 & 104 & 54 & 3 & 6.1 & 58 & 21 & 2 & 8.8 & 19 & & & 34 \\
\hline $\mathrm{Zn}$ & 105 & 77 & 1 & 1.6 & 76 & 85 & 5 & 5.9 & 85 & 131 & 8 & 6.3 & 128 & 125 & & 129 \\
\hline $\mathrm{Ga}$ & 21.0 & 17.3 & 0.3 & 1.5 & 17.4 & 19.8 & 1.0 & 5.1 & 20.3 & 21.5 & 1.2 & 5.7 & 21.6 & 22.0 & & 21.9 \\
\hline $\mathrm{Rb}$ & 9.5 & 20.1 & 0.2 & 1.1 & 20.1 & 66.4 & 1.5 & 2.2 & 68.3 & 46.7 & 1.1 & 2.3 & 48.0 & 47.2 & 46.9 & 48.1 \\
\hline $\mathrm{Sr}$ & 396 & 195 & 2 & 1.0 & 195 & 647 & 32 & 5.0 & 665 & 329 & 7 & 2.1 & 331 & 333 & 340 & 335 \\
\hline Y & 24.9 & 20.5 & 0.2 & 1.0 & 20.3 & 17.9 & 0.3 & 1.5 & 18.7 & 33.4 & 0.5 & 1.6 & 34.7 & 34.0 & & 35.0 \\
\hline $\mathrm{Zr}$ & 165 & 81.1 & 1.2 & 1.4 & 84.3 & 217 & 3 & 1.2 & 220 & 175 & 2 & 1.3 & 184 & 178 & & 184 \\
\hline $\mathrm{Nb}$ & 16.8 & 6.71 & 0.05 & 0.8 & 6.69 & 12.5 & 0.2 & 1.3 & 12.8 & 11.0 & 0.1 & 1.2 & 11.3 & 10.7 & & 11.3 \\
\hline Мо & 1.04 & 0.49 & 0.01 & 1.9 & 0.45 & 2.10 & 0.1 & 3.4 & 2.20 & 265 & 4 & 1.6 & 2 & & & 255 \\
\hline $\mathrm{Cd}$ & 0.069 & 0.046 & 0.002 & 4.2 & 0.057 & 0.065 & 0.005 & 7.4 & 0.099 & 0.20 & 0.01 & 4.6 & 0.13 & & & \\
\hline $\mathrm{Sn}$ & 2.3 & 2.1 & 0.2 & 9.0 & 2.0 & 5.2 & 0.1 & 1.9 & 5.3 & 2.6 & 0.1 & 3.9 & 2.4 & & & \\
\hline $\mathrm{Sb}$ & 0.17 & 0.89 & 0.03 & 3.6 & 0.79 & 4.94 & 0.19 & 3.9 & 4.46 & 0.34 & 0.02 & 5.2 & 0.50 & & & \\
\hline Cs & 0.10 & 0.91 & 0.01 & 1.4 & 0.92 & 1.30 & 0.02 & 1.7 & 1.31 & 1.16 & 0.02 & 1.8 & 0.99 & 1.16 & & 1.18 \\
\hline $\mathrm{Ba}$ & 133 & 171 & 2 & 1.0 & 171 & 1270 & 22 & 1.7 & 1223 & 689 & 20 & 2.9 & 687 & 684 & 677 & 672 \\
\hline $\mathrm{La}$ & 15.5 & 10.4 & 0.1 & 0.9 & 10.6 & 39.5 & 0.7 & 1.9 & 38.5 & 24.8 & 0.4 & 1.6 & 25.5 & 24.9 & 24.9 & 24.4 \\
\hline $\mathrm{Ce}$ & 38.0 & 23.2 & 0.1 & 0.6 & 23.1 & 70.3 & 2.7 & 3.8 & 68.5 & 52.5 & 0.8 & 1.5 & 53.3 & 53.7 & 52.2 & 51.9 \\
\hline $\operatorname{Pr}$ & 5.45 & 3.03 & 0.03 & 1.0 & 3.03 & 8.51 & 0.17 & 2.0 & 8.45 & 6.83 & 0.11 & 1.6 & 6.88 & 6.80 & 6.57 & 6.79 \\
\hline $\mathrm{Nd}$ & 24.7 & 13.0 & 0.2 & 1.2 & 13.0 & 31.7 & 0.6 & 2.0 & 31.6 & 28.4 & 0.5 & 1.6 & 28.8 & 28.8 & 28.7 & 28.4 \\
\hline $\mathrm{Sm}$ & 6.17 & 3.30 & 0.01 & 0.5 & 3.31 & 5.79 & 0.14 & 2.4 & 5.82 & 6.60 & 0.12 & 1.9 & 6.60 & 6.59 & 6.57 & 6.58 \\
\hline $\mathrm{Eu}$ & 2.06 & 1.11 & 0.02 & 1.5 & 1.09 & 1.76 & 0.05 & 2.6 & 1.57 & 2.01 & 0.05 & 2.3 & 1.89 & 1.95 & 1.96 & 1.98 \\
\hline Gd & 6.22 & 3.71 & 0.04 & 1.1 & 3.69 & 5.04 & 0.13 & 2.6 & 4.73 & 6.80 & 0.14 & 2.1 & 6.69 & 6.68 & 6.75 & 6.67 \\
\hline $\mathrm{Tb}$ & 0.95 & 0.62 & 0.01 & 0.7 & 0.62 & 0.67 & 0.02 & 2.5 & 0.66 & 1.07 & 0.02 & 2.2 & 1.07 & & 1.07 & 1.06 \\
\hline
\end{tabular}




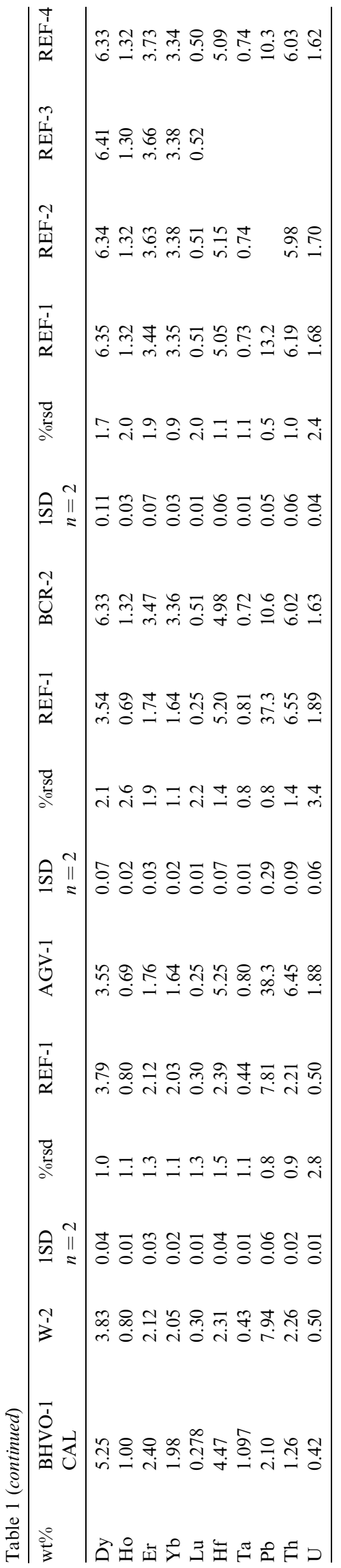

diffusion of gas during sustained heating (Turner, 1968). We conclude that the simple age spectra obtained on the 67016 anorthositic clasts preserve a common age. The weighted mean age calculated from all analyses of these four clasts is $3863 \pm 12 \mathrm{Ma}(95 \%$ confidence, $n=7$, $\mathrm{MSWD}=1.3$; Fig. 5). Deleting analysis ,384X-B from the calculation yields a weighted mean of $3868 \pm 9 \mathrm{Ma}(95 \%$ confidence, $n=6$, MSWD $=0.41$ ).

Three anorthosite clasts from 67455 yielded a somewhat larger range of plateau ages that extends to both younger and older values (3801-4012 Ma; Table 4 and Fig. 4) compared to the 67016 anorthositic clasts. All of the release spectra for these clasts show clear evidence for diffusive loss in the low-T heating steps (Fig. 4), but no distinct high temperature, undegassed phase in either the age spectra or the $\mathrm{K} / \mathrm{Ca}$ spectra. Replicate analyses of two of these clasts do not agree within analytical error of the individual measurements (Table 4 and Fig. 5). The plateau age of split-B from ferroan noritic anorthosite clast 67455,275 (3801 $\pm 29 \mathrm{Ma})$ is probably biased to an unrealistically low value by several intermediate temperature steps that give ages as low as 3.23.5 Ga (see Electronic Annex files 'Annex A-Plateau.pdf' and 'Annex B-Ar Data.xls'); a more conservative plateau choice of the 6 highest-T steps representing $23.7 \%$ of released ${ }^{39} \mathrm{Ar}$ yields an age that is within error of that obtained on split-C of this sample $(3883 \pm 60 \mathrm{Ma}$ vs. $3871 \pm 39 \mathrm{Ma}$; Table 4). These clasts have clearly had a somewhat different thermal history from those in 67016, with a remarkably uniform set of low-T step ages at 2.0 $2.5 \mathrm{Ga}$ (Fig. 4). It is possible, then, that they have experienced variable resetting of their initial formation ages, from complete (,271B and ,275C, which give plateau ages identical to the 67016 anorthositic clasts) to about $98-99 \%$ degassed (,271C and ,273B and C), followed by secondary reheating in the period $2.0-2.5 \mathrm{Ga}$. The weighted mean age of anorthositic clasts from 67455 (3935 $\pm 86 \mathrm{Ma} ; 95 \%$ confidence, $n=6$, MSWD $=37$; Fig. 5) has a large uncertainty that overlaps the mean age of anorthositic clasts from 67016 .

In contrast to the anorthositic lithologies, melt breccia clasts from 67016 yielded more complex age spectra, with systematically older plateaus and evidence for even older age components in their high-T release fractions. Plateau ages of the 67016 melt breccia clasts defined by intermediate temperature release steps range from 4014 to $4188 \mathrm{Ma}$, with a weighted mean of $4112 \pm 34$ Ma (Figs. 6 and 7). Higher-T steps in most of the 67016 melt breccia clast spectra indicate undegassed components with ages possibly as old as 4.4 4.5 Ga (Figs. 6 and 7; Electronic Annex). Low-T fractions from the 67016 melt breccia clasts show evidence for diffusive loss, at 3.8-3.9 Ga (Fig. 8). Our estimate of the timing of this final heating event is imprecise given the rather large uncertainties on the lowest-T step ages, but the $3868 \mathrm{Ma}$ age obtained from the anorthositic clasts certainly is permissible. The single analysis of a melt breccia clast from 67455 (,277B) gave a plateau age of $3987 \pm 21 \mathrm{Ma}$ (Table 4 and Fig. 4), within the age range of the 67455 anorthostic clasts. In contrast to the 67016 melt breccia clasts, there is no obvious evidence for a distinct, high-T older component in this sample, in either the age spectrum or the K/Ca spectrum. 
Table 2

Major and trace element compositions of clasts from lunar breccias 67016 and 67455. Lithologies: sodic anorthosite (NaAN), melt breccia (MBX), granulite (GRAN), mafic-poor ferroan anorthosite (AN), noritic anorthosite (FeAN). $\mathrm{SiO}_{2}$ by difference. nd, not detected.

\begin{tabular}{|c|c|c|c|c|c|c|c|c|c|c|c|}
\hline \multirow{3}{*}{$\begin{array}{l}\text { Split } \\
\text { lithology }\end{array}$} & \multicolumn{7}{|l|}{67016} & \multicolumn{4}{|l|}{67455} \\
\hline &, $384 X$ & ,385 &, 386 & ,387 & ,388 & 390 & ,392 & ,271 & ,273 & ,275 & ,277 \\
\hline & $\mathrm{NaAN}$ & MBX & MBX & MBX & MBX & GRAN & MBX & $\mathrm{AN}$ & AN & $\mathrm{FeAN}$ & MBX \\
\hline \multicolumn{12}{|l|}{$w t \%$} \\
\hline $\mathrm{SiO}_{2}$ & 48.2 & 47.3 & 47.0 & 46.0 & 47.2 & 46.7 & 47.4 & 47.9 & 45.4 & 44.6 & 46.6 \\
\hline $\mathrm{TiO}_{2}$ & 0.08 & 0.27 & 0.26 & 0.29 & 0.27 & 0.23 & 0.35 & 0.05 & 0.07 & 0.14 & 0.53 \\
\hline $\mathrm{Al}_{2} \mathrm{O}_{3}$ & 32.1 & 29.7 & 30.2 & 30.7 & 29.8 & 25.3 & 29.6 & 33.2 & 33.5 & 29.0 & 29.8 \\
\hline $\mathrm{FeOt}$ & 1.01 & 3.11 & 2.98 & 3.07 & 3.15 & 4.83 & 3.30 & 0.60 & 1.27 & 5.50 & 3.30 \\
\hline $\mathrm{MnO}$ & 0.015 & 0.042 & 0.042 & 0.044 & 0.044 & 0.059 & 0.047 & 0.010 & 0.018 & 0.072 & 0.048 \\
\hline $\mathrm{MgO}$ & 0.81 & 2.81 & 2.58 & 2.73 & 2.73 & 8.64 & 2.88 & 0.41 & 1.37 & 4.23 & 2.86 \\
\hline $\mathrm{CaO}$ & 17.0 & 16.2 & 16.4 & 16.6 & 16.3 & 13.7 & 15.9 & 17.6 & 18.1 & 16.2 & 16.3 \\
\hline $\mathrm{Na}_{2} \mathrm{O}$ & 0.73 & 0.51 & 0.44 & 0.48 & 0.45 & 0.34 & 0.47 & 0.27 & 0.28 & 0.21 & 0.47 \\
\hline $\mathrm{K}_{2} \mathrm{O}$ & 0.08 & 0.07 & 0.05 & 0.07 & 0.06 & 0.16 & 0.01 & 0.02 & 0.04 & 0.03 & 0.04 \\
\hline \multicolumn{12}{|c|}{ ppm except as noted } \\
\hline $\mathrm{Li}$ & 9.4 & 8.7 & 7.6 & 9.0 & 7.8 & 7.5 & 7.9 & 2.7 & 2.8 & 3.1 & 5.1 \\
\hline $\mathrm{Sc}$ & 2.7 & 6.0 & 5.8 & 6.0 & 6.2 & 6.3 & 7.7 & 1.7 & 2.3 & 8.3 & 7.0 \\
\hline $\mathrm{V}$ & 3.2 & 9.3 & 9.2 & 9.2 & 9.5 & 18.2 & 11.3 & 4.1 & 6.8 & 12.2 & 11.1 \\
\hline $\mathrm{Cr}$ & 81 & 292 & 300 & 301 & 296 & 658 & 366 & 48 & 149 & 294 & 351 \\
\hline $\mathrm{Co}$ & 1.1 & 8.5 & 7.3 & 7.1 & 7.1 & 15.3 & 8.6 & 1.1 & 4.3 & 3.9 & 15.5 \\
\hline $\mathrm{Ni}$ & 3 & 55 & 33 & 33 & 31 & 134 & 66 & 3 & 10 & 5 & 89 \\
\hline $\mathrm{Cu}$ & 1.0 & 2.1 & 2.0 & 2.3 & 2.1 & 2.6 & 3.0 & 1.2 & 1.2 & 1.4 & 5.1 \\
\hline $\mathrm{Zn}$ & 3.5 & 3.0 & 2.3 & 2.4 & 2.2 & 9.4 & 4.2 & 1.8 & 2.5 & 10.7 & 3.6 \\
\hline $\mathrm{Ga}$ & 6.7 & 4.0 & 3.6 & 3.7 & 3.5 & 3.4 & 3.5 & 3.4 & 3.3 & 2.8 & 3.8 \\
\hline $\mathrm{Rb}$ & 1.3 & 0.9 & 0.9 & 1.4 & 0.9 & 1.0 & 0.8 & 0.8 & 0.8 & 0.5 & 0.5 \\
\hline $\mathrm{Sr}$ & 331 & 207 & 190 & 193 & 188 & 156 & 178 & 160 & 160 & 142 & 212 \\
\hline $\mathrm{Y}$ & 1.7 & 14.0 & 10.7 & 12.8 & 10.4 & 16.8 & 11.8 & 1.2 & 1.7 & 3.3 & 9.5 \\
\hline $\mathrm{Zr}$ & 2.7 & 51.6 & 41.9 & 46.1 & 44.1 & 69.2 & 46.2 & 2.6 & 4.4 & 8.3 & 35.8 \\
\hline $\mathrm{Nb}$ & 0.3 & 3.4 & 2.7 & 3.3 & 2.6 & 4.8 & 2.9 & 0.2 & 0.3 & 0.4 & 2.4 \\
\hline $\mathrm{Cd}$ ppb & 2 & 9 & 4 & 12 & 8 & 14 & 8 & 2 & 1 & 2 & 7 \\
\hline Sn ppb & 68 & 36 & 33 & 37 & 155 & 66 & 45 & 72 & 134 & 219 & 45 \\
\hline $\mathrm{Sb} \mathrm{ppb}$ & nd & 1.4 & 4.8 & 1.2 & 4.3 & 1.8 & 5.7 & 4.4 & 16.0 & 2.0 & 1.1 \\
\hline Cs ppb & 83 & 61 & 42 & 54 & 36 & 18 & 38 & 43 & 52 & 36 & 26 \\
\hline $\mathrm{Ba}$ & 40.1 & 68.3 & 50.1 & 61.8 & 47.8 & 73.1 & 50.5 & 8.9 & 9.9 & 9.9 & 43.1 \\
\hline $\mathrm{La}$ & 0.79 & 4.13 & 3.02 & 3.56 & 2.82 & 5.22 & 3.23 & 0.27 & 0.43 & 0.55 & 2.60 \\
\hline $\mathrm{Ce}$ & 1.79 & 10.73 & 7.80 & 9.22 & 7.33 & 13.37 & 8.43 & 0.69 & 1.10 & 1.46 & 6.72 \\
\hline $\operatorname{Pr}$ & 0.24 & 1.49 & 1.09 & 1.29 & 1.02 & 1.80 & 1.18 & 0.10 & 0.15 & 0.21 & 0.94 \\
\hline $\mathrm{Nd}$ & 1.04 & 6.58 & 4.89 & 5.72 & 4.63 & 7.79 & 5.29 & 0.46 & 0.68 & 1.01 & 4.24 \\
\hline $\mathrm{Sm}$ & 0.28 & 1.86 & 1.39 & 1.66 & 1.32 & 2.14 & 1.55 & 0.14 & 0.19 & 0.32 & 1.26 \\
\hline $\mathrm{Eu}$ & 2.00 & 1.27 & 1.09 & 1.12 & 1.06 & 0.94 & 1.04 & 0.72 & 0.74 & 0.68 & 1.20 \\
\hline $\mathrm{Gd}$ & 0.29 & 2.16 & 1.63 & 1.93 & 1.56 & 2.44 & 1.84 & 0.18 & 0.24 & 0.43 & 1.47 \\
\hline $\mathrm{Tb}$ & 0.048 & 0.39 & 0.30 & 0.35 & 0.28 & 0.45 & 0.33 & 0.033 & 0.045 & 0.081 & 0.27 \\
\hline Dy & 0.30 & 2.48 & 1.89 & 2.26 & 1.82 & 2.90 & 2.11 & 0.21 & 0.30 & 0.56 & 1.69 \\
\hline Ho & 0.064 & 0.54 & 0.41 & 0.49 & 0.40 & 0.64 & 0.46 & 0.043 & 0.067 & 0.13 & 0.37 \\
\hline $\mathrm{Er}$ & 0.17 & 1.44 & 1.11 & 1.31 & 1.07 & 1.76 & 1.24 & 0.13 & 0.19 & 0.36 & 1.00 \\
\hline $\mathrm{Yb}$ & 0.17 & 1.43 & 1.12 & 1.32 & 1.07 & 1.89 & 1.22 & 0.13 & 0.20 & 0.38 & 0.99 \\
\hline $\mathrm{Lu}$ & 0.024 & 0.20 & 0.16 & 0.19 & 0.16 & 0.28 & 0.18 & 0.018 & 0.029 & 0.057 & 0.14 \\
\hline $\mathrm{Hf}$ & 0.081 & 1.34 & 1.09 & 1.26 & 1.12 & 1.79 & 1.21 & 0.070 & 0.13 & 0.24 & 0.97 \\
\hline $\mathrm{Ta}$ & 0.011 & 0.17 & 0.14 & 0.17 & 0.13 & 0.25 & 0.15 & 0.011 & 0.014 & 0.024 & 0.13 \\
\hline Th & 0.022 & 0.68 & 0.50 & 0.72 & 0.47 & 1.24 & 0.49 & 0.021 & 0.051 & 0.054 & 0.38 \\
\hline $\mathrm{U}$ & 0.005 & 0.18 & 0.13 & 0.19 & 0.13 & 0.36 & 0.13 & 0.005 & 0.013 & 0.013 & 0.11 \\
\hline
\end{tabular}

\section{DISCUSSION}

\subsection{Provenance of the Descartes breccias}

Major and trace element compositions of clasts in the Descartes breccias span a broad range indicating diverse components contributing to these breccias. In 67016 and 67455 the anorthositic clasts have compositions that range continuously from nearly pure anorthosite with $\sim 35 \mathrm{wt} \%$ $\mathrm{Al}_{2} \mathrm{O}_{3}$ to noritic anorthosite with $21-23 \mathrm{wt} \% \mathrm{Al}_{2} \mathrm{O}_{3}$, reflecting variable proportions of plagioclase and mafic silicates (Fig. 1). In contrast, the melt breccia clasts have a more restricted range of intermediate compositions that cluster around the whole rocks (Fig. 1). A cogenetic origin for the clasts and the host fragmental breccias is indicated, with the melt breccia clasts and the bulk fragmental breccias 


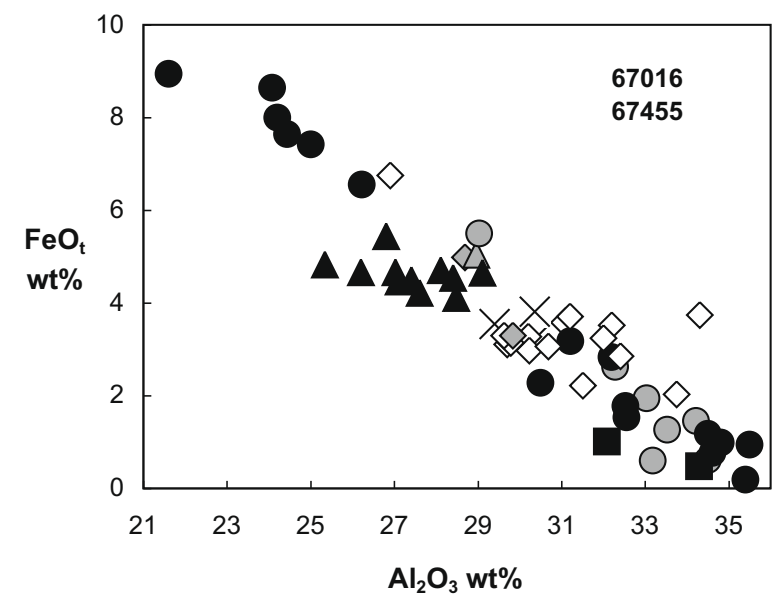

Fig. 1. $\mathrm{Al}_{2} \mathrm{O}_{3}$ vs. $\mathrm{FeO}_{\mathrm{t}}$ contents of clasts and whole rock samples of Descartes breccias 67016 and 67455. Anorthositic clasts define extremes of the compositional range whereas melt breccia clasts have intermediate compositions that cluster near those of the host fragmental breccia. Symbols: ferroan anorthosites and ferroan noritic anorthosite clasts (filled circles), sodic anorthosite clasts (filled squares), granulitic breccia clasts (filled triangles), melt breccia clasts (diamonds), bulk host breccia (X). 67455 clasts are plotted as filled gray symbols. 67016 clasts are plotted as filled black (anorthositic, granulitic) or open (melt breccia) symbols. $\mathrm{FeO}_{\mathrm{t}}$, total $\mathrm{Fe}$ as $\mathrm{FeO}$. Data from this study (Table 2), Lindstrom et al. (1977); Lindstrom and Salpas (1983), and Norman and Taylor (1992).

sampling related suites of anorthositic crustal lithologies in about the same proportions. Similarities in petrology and geochemistry of the anorthositic clasts across the Descartes breccia suite (Lindstrom and Salpas, 1983) and the lack of regolith components in these breccias (Norman, 1981) further suggest a common source region and a lack of postdepositional reworking of unconsolidated material at the lunar surface. The Descartes breccias are most likely a coherent deposit of impact breccia rather than mixtures of unrelated debris transported to the site from diverse locations. This implies a provenance of these breccias from a relatively restricted volume of lunar crust that was excavated and deposited at the Apollo 16 site by a single impact event. Our interpretation emphasizing the transport and codeposition of anorthositic clasts, feldspathic melt breccia clasts, and bulk host breccia differs from that of Korotev (1997), who regarded most of the feldspathic Descartes material as locally derived.

Lithologic affinities of the crustal components in these Descartes breccias can be evaluated using key trace element ratios. The widely recognized suites of feldspathic cumulates comprising the lunar highlands crust (e.g., ferroan anorthositic suite, Mg-suite norites, troctolites, and alkali anorthosites) have diagnostic signatures in trace element ratios such as $\mathrm{Sr} / \mathrm{Ba}, \mathrm{Ti} / \mathrm{Sm}$, and $\mathrm{Sc} / \mathrm{Sm}$ that apparently reflect melt evolution in a magma ocean and the development of KREEP (Norman and Ryder, 1980; Warren et al., 1983; Warren and Kallemeyn, 1984; Norman et al., 2003).

Melt breccia and anorthositic clasts from 67016 and 67455 have $\mathrm{Sr} / \mathrm{Ba}, \mathrm{Ti} / \mathrm{Sm}$, and $\mathrm{Sc} / \mathrm{Sm}$ ratios that change systematically to lower values with increasing incompatible element concentrations (Fig. 2). Three of the mafic-poor anorthosite clasts have very low abundances of incompatible trace elements, large positive Eu anomalies, superchondritic $\mathrm{Sr} / \mathrm{Ba}$, and $\mathrm{Ti} / \mathrm{Sm}$ and $\mathrm{Sc} / \mathrm{Sm}$ ratios that are within the ranges observed for pristine ferroan anorthosites (Fig. 2; cf. Lindstrom et al., 1977; Norman and Ryder, 1980; Warren and Kallemeyn, 1984; Norman et al., 2003). In contrast, the melt breccia and granulite clasts have higher incompatible element abundances, with $\mathrm{Sr} / \mathrm{Ba}, \mathrm{Ti} / \mathrm{Sm}$, and $\mathrm{Sc} / \mathrm{Sm}$ all trending to lower values with increasing incompatible element concentrations, consistent with incorporation of KREEPy and/or Mg-suite lithologies into these clasts (Fig. 2).

Although the feldspathic Descartes breccias have among the lowest levels of incompatible elements of any suite of lunar impact breccias (Lindstrom and Salpas, 1981, 1983), previous studies of other fragmental breccias from the North Ray crater stations also commented on the presence of KREEP-rich components. For example, KREEP-rich melt rocks occur as clasts in the feldspathic fragmental breccias 67015 (Marvin and Lindstrom, 1983; Marvin et al., 1987) and 67055 (Lindstrom and Salpas, 1983), and 67975 contains clasts that "strongly resemble Apollo 14 gabbronorites and alkali anorthosites both in their mineral composition and their high REE and phosphate contents" (Lindstrom, 1984). Rare clasts of "KREEP basalt" and REE-enriched sodic ferrogabbro are also present in 67016 (Norman, 1981; Lindstrom and Salpas, 1983).

The presence of KREEP-rich components in the Descartes breccias has significant implications for the provenance of these breccias. Global mapping of $\mathrm{K}$ and $\mathrm{Th}$ concentrations on the surface of the Moon revealed an anomalous enrichment of these elements in the Oceanus Procellarum region (Lawrence et al., 2000). Jolliff et al. (2000) referred to this region as the Procellarum-KREEP Terrane (PKT). The Imbrium impact occurred within the PKT, distributing KREEP-bearing ejecta across the lunar surface, whereas there is little or no evidence in the Lunar Prospector data that the Nectaris basin excavated significant amounts of KREEP (Korotev, 1997). Although KREEP-rich clasts constitute a minor fraction of the Descartes breccias, the petrography and trace element compositions of these clasts point toward a provenance of the breccias in the Procellarum-KREEP Terrane, linking them with Imbrium rather than Nectaris. If the Cayley and Descartes units are both facies of Imbrium ejecta, the differences in morphology, bulk composition, and the relative proportions of KREEP vs. ferroan anorthosite, may preserve information about the pre-impact stratigraphy or lateral heterogeneity in the lunar crust, and the processes of ejecta deposition during a basin-forming impact event.

\subsection{Assembly of the Descartes breccias}

Fig. 9 compares all ages obtained by this study with those of Maurer et al. (1978). By examination of this diagram and related probability plots (Ludwig, 1999) we identified three groups of samples that appear most likely to represent related age populations, and calculated 

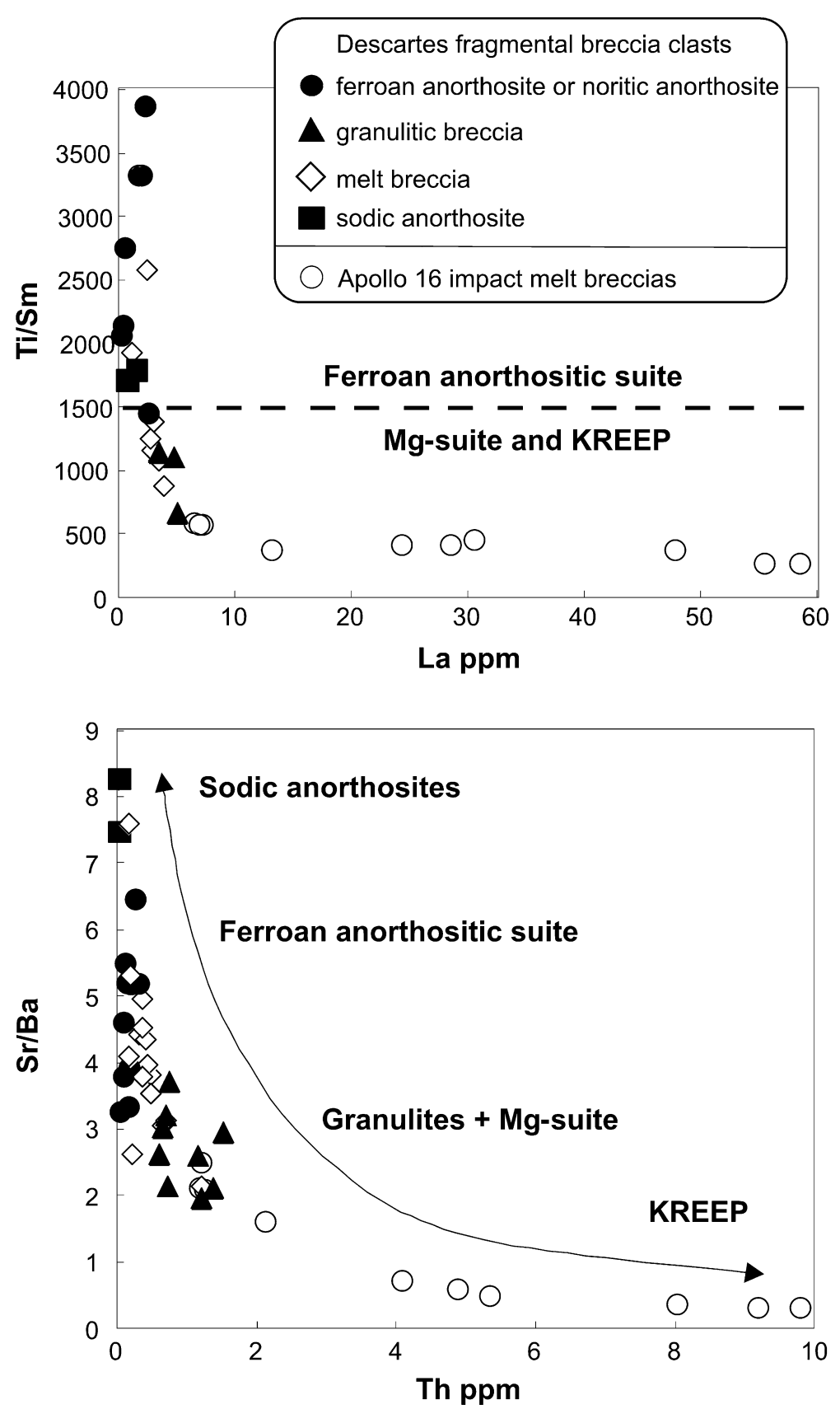

Fig. 2. Plots of $\mathrm{La}$ vs Ti/Sm and Th vs. Sr/Ba for the 67016 and 67455 clasts compared to a representative group of Apollo 16 impact melt breccias (open circles). The 67016 and 67455 clasts have generally lower levels of incompatible trace elements and higher $\mathrm{Ti} / \mathrm{Sm}$ and $\mathrm{Sr} / \mathrm{Ba}$ ratios compared to the impact melt breccias, but all samples fall along similar trends suggestive of mixing between anorthositic rocks and KREEP-bearing lithologies. The line at $\mathrm{Ti} / \mathrm{Sm}=1500$ that divides ferroan anorthositic suite rocks from the Mg-suite and KREEP is after Norman and Ryder (1980; see also Warren et al., 1983). Plots of Sc/Sm vs. incompatible element concentrations show similar trends with the 67016-67455 clasts having systematically higher $\mathrm{Sc} / \mathrm{Sm}$ and falling along extensions of the melt breccia trends. As for the major elements (Fig. 1), the 67016 and 67455 melt breccia clasts (open diamonds) have more restricted ranges of trace element abundances compared to the anorthositic (filled circles and squares) and granulitic (filled triangles) clasts. 67016 and 67455 data from this study (Table 2), Lindstrom and Salpas (1983), Norman and Taylor (1992). Apollo 16 impact melt rock data from Table 3.

weighted mean ages for each group. Assignment of individual analyses to these groups was somewhat subjective and guided by optimization of errors. Alternate groupings can be selected for any age calculation, but the results presented here illustrate the general relationships within this set of data.
The youngest group includes the seven analyses of anorthositic clasts from 67016, anorthositic clast analyses ,275C and ,271B from 67455, and fragments ME-1, LK-1, and LN-1 from Maurer et al. (1978). The weighted mean age for this group is $3866 \pm 9 \mathrm{Ma}(95 \%$ confidence, $n=12$, MSWD $=1.3$, which is identical with the result obtained 
Table 3

Major and trace element compositions of Apollo 16 impact melt breccias. 'Group' is from Korotev (1994). $\mathrm{SiO}_{2}$ is by difference, nd, not detected, na, not analyzed.

\begin{tabular}{|c|c|c|c|c|c|c|c|c|c|c|c|c|c|c|}
\hline \multirow{3}{*}{$\begin{array}{l}\text { Split } \\
\text { Group } \\
\text { Replicate }\end{array}$} & \multirow{2}{*}{\multicolumn{3}{|c|}{$\begin{array}{l}60315,224 \\
1 \mathrm{M}\end{array}$}} & \multirow{3}{*}{$\begin{array}{l}62235,60 \\
1 \mathrm{~F}\end{array}$} & \multirow{3}{*}{$\begin{array}{l}65015,49 \\
1 \mathrm{~F}\end{array}$} & \multirow{3}{*}{$\begin{array}{l}63355,56 \\
1 \mathrm{~F}\end{array}$} & \multirow{2}{*}{\multicolumn{3}{|c|}{$\begin{array}{l}66095,25 \\
2 \mathrm{NR}\end{array}$}} & \multirow{3}{*}{$\begin{array}{l}67235,8 \\
2 \mathrm{NR}\end{array}$} & \multirow{3}{*}{$\begin{array}{l}60335,6 \\
2 \mathrm{~F}\end{array}$} & \multirow{3}{*}{$\begin{array}{l}65055,39 \\
3\end{array}$} & \multirow{3}{*}{$\begin{array}{l}68415,211 \\
3\end{array}$} & \multirow{3}{*}{$\begin{array}{l}68416,20 \\
3\end{array}$} \\
\hline & & & & & & & & & & & & & & \\
\hline & $\overline{\mathrm{A}}$ & B & $\overline{\text { Average }}$ & & & & $\bar{A}$ & B & $\overline{\text { Average }}$ & & & & & \\
\hline \multicolumn{15}{|l|}{$\overline{w t \%}$} \\
\hline $\mathrm{SiO}_{2}$ & 48.7 & 48.0 & 48.3 & 48.5 & 44.2 & 44.5 & 45.6 & 44.7 & 45.2 & 47.7 & 47.5 & 46.1 & 48.3 & 47.0 \\
\hline $\mathrm{TiO}_{2}$ & 1.34 & 1.35 & 1.34 & 1.18 & 1.15 & 1.09 & 0.76 & 0.78 & 0.77 & 0.90 & 0.37 & 0.30 & 0.32 & 0.31 \\
\hline $\mathrm{Al}_{2} \mathrm{O}_{3}$ & 16.6 & 16.9 & 16.8 & 18.8 & 21.4 & 20.8 & 22.1 & 23.0 & 22.6 & 20.7 & 28.7 & 28.5 & 27.3 & 28.1 \\
\hline $\mathrm{FeO}_{\mathrm{t}}$ & 8.8 & 8.8 & 8.8 & 9.1 & 8.7 & 8.6 & 7.9 & 7.7 & 7.8 & 6.7 & 2.8 & 4.0 & 4.1 & 4.1 \\
\hline $\mathrm{MnO}$ & 0.115 & 0.118 & 0.116 & 0.112 & 0.119 & 0.101 & 0.083 & 0.084 & 0.083 & 0.091 & 0.044 & 0.056 & 0.057 & 0.057 \\
\hline $\mathrm{MgO}$ & 13.7 & 13.9 & 13.8 & 10.4 & 10.5 & 11.5 & 10.1 & 10.3 & 10.2 & 11.3 & 4.4 & 4.5 & 4.3 & 4.5 \\
\hline $\mathrm{CaO}$ & 9.9 & 10.0 & 10.0 & 11.2 & 12.4 & 12.3 & 12.8 & 12.9 & 12.8 & 11.9 & 15.6 & 16.0 & 15.2 & 15.5 \\
\hline $\mathrm{Na}_{2} \mathrm{O}$ & 0.56 & 0.56 & 0.56 & 0.46 & 0.65 & 0.55 & 0.41 & 0.41 & 0.41 & 0.41 & 0.53 & 0.42 & 0.39 & 0.42 \\
\hline $\mathrm{K}_{2} \mathrm{O}$ & 0.33 & 0.35 & 0.34 & 0.29 & 0.40 & 0.28 & 0.13 & 0.18 & 0.15 & 0.25 & 0.13 & 0.06 & 0.10 & 0.09 \\
\hline $\mathrm{P}_{2} \mathrm{O}_{5}$ & na & na & na & na & 0.59 & 0.30 & na & na & na & na & na & na & na & na \\
\hline \multicolumn{15}{|c|}{ ppm except as noted } \\
\hline $\mathrm{Li}$ & 22.3 & 22.8 & 22.5 & 22.6 & 26.1 & 19.0 & 13.3 & 13.1 & 13.2 & 13.9 & 9.3 & 5.5 & 6.3 & 5.0 \\
\hline $\mathrm{Sc}$ & 14.8 & 14.9 & 14.8 & 16.7 & 16.8 & 14.1 & 10.3 & 10.5 & 10.4 & 12.5 & 5.5 & 8.0 & 8.7 & 8.6 \\
\hline $\mathrm{V}$ & 38.3 & 39.2 & 38.7 & 36.2 & 41.2 & 38.7 & 27.1 & 27.0 & 27.1 & 32.4 & 13.8 & 17.9 & 19.5 & 19.8 \\
\hline $\mathrm{Cr}$ & 1369 & 1405 & 1387 & 1234 & 1430 & 1419 & 971 & 979 & 975 & 1128 & 457 & 610 & 675 & 678 \\
\hline $\mathrm{Co}$ & 43.1 & 41.5 & 42.3 & 48.5 & 28.7 & 50.4 & 71.1 & 58.1 & 64.6 & 21.5 & 8 & 13.8 & 13.4 & 11.6 \\
\hline $\mathrm{Ni}$ & 715 & 676 & 696 & 633 & 490 & 751 & 1109 & 899 & 1004 & 318 & 163 & 116 & 119 & 99 \\
\hline $\mathrm{Cu}$ & 8.4 & 8.4 & 8.4 & 7.1 & 7.7 & 7.5 & 7.6 & 7.0 & 7.3 & 5.5 & 3.3 & 3.6 & 3.3 & 3.4 \\
\hline $\mathrm{Zn}$ & 5.6 & 5.8 & 5.7 & 5.1 & 5.0 & 10.1 & 47.8 & 43.7 & 45.7 & 10.3 & 2.2 & 2.1 & 2.4 & 2.2 \\
\hline $\mathrm{Ga}$ & 5.3 & 5.4 & 5.4 & 5.5 & 5.7 & 5.4 & 4.4 & 4.2 & 4.3 & 4.6 & 3.9 & 2.5 & 2.7 & 2.7 \\
\hline $\mathrm{Rb}$ & 10.7 & 10.7 & 10.7 & 9.1 & 9.6 & 6.7 & 4.1 & 4.1 & 4.1 & 6.4 & 4.0 & 1.8 & 1.8 & 1.8 \\
\hline $\mathrm{Sr}$ & 151 & 152 & 152 & 157 & 173 & 163 & 152 & 150 & 151 & 151 & 200 & 175 & 176 & 176 \\
\hline $\mathrm{Y}$ & 150 & 149 & 150 & 179 & 192 & 97 & 78 & 77 & 77 & 90 & 42 & 22 & 24 & 23 \\
\hline $\mathrm{Zr}$ & 682 & 685 & 683 & 815 & 758 & 429 & 332 & 326 & 329 & 389 & 177 & 90 & 98 & 92 \\
\hline $\mathrm{Nb}$ & 38.7 & 40.4 & 39.5 & 45.9 & 48.2 & 28.7 & 19.3 & 19.2 & 19.3 & 22.8 & 9.7 & 5.7 & 6.1 & 5.7 \\
\hline $\mathrm{Cd} \mathrm{ppb}$ & 133 & 136 & 134 & 158 & 156 & 91 & 191 & 183 & 187 & 68 & 34 & 15 & 15 & 16 \\
\hline Sn ppb & 9 & 13 & 11 & 9 & nd & nd & 1368 & 1302 & 1335 & 38 & 10 & 7 & 17 & 27 \\
\hline $\mathrm{Sb} \mathrm{ppb}$ & 13.2 & 12.9 & 13.0 & 9.7 & 9.7 & 28.2 & 6.6 & 9.7 & 8.2 & 15.3 & 9 & 2.1 & nd & 5.8 \\
\hline Cs ppb & 571 & 573 & 572 & 471 & 542 & 322 & 184 & 184 & 184 & 244 & 172 & 87 & 96 & 94 \\
\hline $\mathrm{Ba}$ & 493 & 498 & 496 & 595 & 562 & 329 & 247 & 247 & 247 & 300 & 138 & 80 & 86 & 83 \\
\hline $\mathrm{La}$ & 48.5 & 49.1 & 48.8 & 59.8 & 55.6 & 30.6 & 24.9 & 25.0 & 24.9 & 29.2 & 13.4 & 6.73 & 7.4 & 7.11 \\
\hline
\end{tabular}




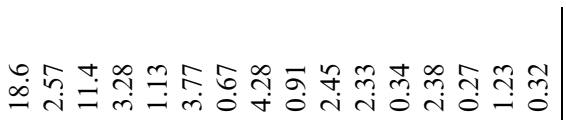

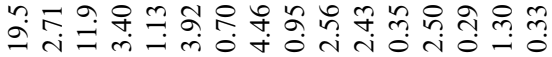

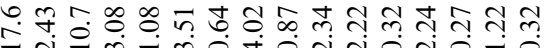

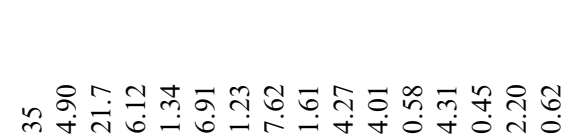

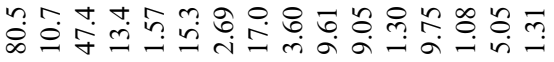

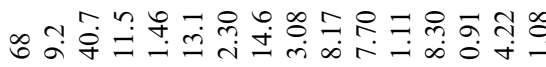

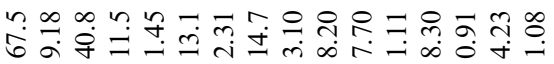

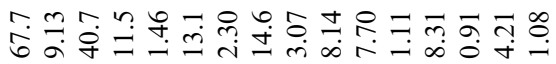

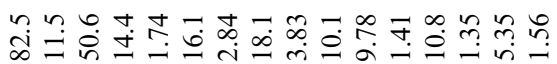

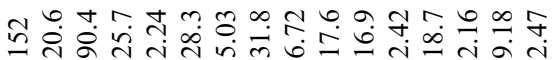

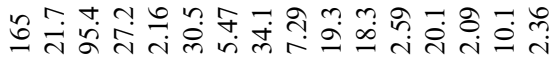

m

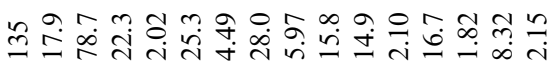

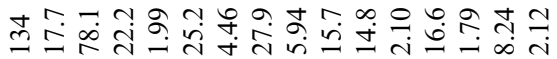

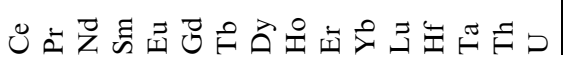

from the 67016 anorthositic clasts alone (Figs. 5 and 9). The anomalously young age of $3801 \pm 29 \mathrm{Ma}$ on $67455,275 \mathrm{~B}$ was ignored for reasons described in the previous section. Including the three next-oldest regolith fragments (NF-1, NG-1, MQ-1, all granulites; see Fig. 9) in the group gives a weighted mean age of $3869 \pm 9 \mathrm{Ma} \quad(n=15$, MSWD $=1.5$ ). The argon data for this group provide generally simple and well-behaved plateaus, and the reproducible ages of the 67016 anorthositic clasts suggest that the age of this youngest group likely records a real event. The most straightforward interpretation is that these clasts outgassed completely during deposition and cooling of the breccia units, such that the youngest group of clasts and regolith fragments dates the deposition the Descartes breccias at 3863-3869 Ma. As the breccias cannot be older than the clasts contained within them, this at least defines an upper limit to the emplacement age of these breccias. Stöffler et al. (1985) also concluded that the Descartes breccias were emplaced at $3.85 \pm 0.05 \mathrm{Ga}$ based on the tight cluster of ${ }^{40} \mathrm{Ar}-{ }^{39} \mathrm{Ar}$ ages obtained from granulitic rocks from the North Ray crater area.

Emplacement mechanisms of the Descartes breccias and the Cayley plains unit, and the relative proportions of locally entrained vs. transported material in basin ejecta deposits, are not well established but the age and geochemical data point toward a close petrogenetic relationship of these units. A feldspathic component similar in composition to the Descartes breccias is present in well-mixed Cayley soils across the landing site (Korotev, 1997), and the timing of Descartes breccia emplacement is within the range of crystallization ages obtained from Apollo 16 impact melt breccias (Norman et al., 2006; Fig. 10). The two most mafic groups of melt breccias (mafic poikilitic, troctolitic vitrophyre) have mean ages identical with that of the Descartes breccias $(3.86-3.87 \mathrm{Ga})$, whereas two groups of more aluminous melt breccias (aluminous subophitic, aluminous poikilitic) have somewhat younger ages (3.77$3.84 \mathrm{Ga}$ ) (Fig. 10). An interpretation consistent with the geochemical and age constraints is that the KREEP-rich, mafic poikilitic breccias were emplaced with the Cayley plains unit as Imbrium impact melt (Korotev, 1997). The younger, more aluminous melt breccias would then be produced by later events and transported independently to the Apollo 16 site. This might be consistent with the relatively small and variable contribution of the aluminous melt breccias to the local soil (e.g., $3 \pm 7 \%$ inferred for Group-3 melt breccias by Korotev, 1997). Hypotheses that consider the aluminous melt breccias as 'pre-basin' deposits or Nectaris ejecta appear to be excluded by the age relationships.

Ages obtained from melt lithologies in the Apollo 16 dimict breccias (3.89-3.96 Ga; Norman et al., 2006) might indicate an older event, either in the Imbrium area prior to basin formation or more proximal to the Apollo 16 site, but these ages are suspect due to the poor quality ${ }^{40} \mathrm{Ar}-{ }^{39} \mathrm{Ar}$ plateaus and the possibility of incomplete degassing during dike emplacement, by analogy with the Descartes melt breccia clasts. Currently it is impossible to link any of the Apollo 16 melt breccias to specific basins or craters with confidence. 
Table 4

${ }^{40} \mathrm{Ar} /{ }^{39} \mathrm{Ar}$ radiometric age determinations of clasts from lunar breccias 67016 and 67455.

\begin{tabular}{|c|c|c|c|c|c|c|c|c|c|}
\hline Sample & Lithology & Plateau age $(\mathrm{Ma})$ & $2 \sigma$ & $\% 39 \mathrm{Ar}$ & Steps & MSWD & Total fusion age (Ma) & $\mathrm{K}_{2} \mathrm{O} \mathrm{wt}^{\circ} \%$ & $\mathrm{mg}$ \\
\hline \multicolumn{10}{|l|}{67455} \\
\hline ,271 B & $\mathrm{AN}$ & 3889 & 23 & 59.8 & $13 / 26$ & 1.92 & 3753 & 0.02 & 2.77 \\
\hline, $271 \mathrm{C}$ & & 3972 & 31 & 70.9 & $10 / 19$ & 2.18 & 3868 & 0.02 & 0.79 \\
\hline, $273 \mathrm{~B}$ & $\mathrm{AN}$ & 3987 & 27 & 68.2 & $10 / 18$ & 1.44 & 3871 & 0.04 & 0.92 \\
\hline, $273 \mathrm{C}$ & & 4012 & 21 & 65.7 & $13 / 30$ & 0.94 & 3896 & 0.04 & 1.57 \\
\hline, $275 \mathrm{~B}$ & $\mathrm{FeAN}$ & 3801 & 29 & 74.3 & $24 / 32$ & 1.46 & 3683 & 0.03 & 1.91 \\
\hline, $277 \mathrm{~B}$ & MBX & 3987 & 21 & 77.8 & $17 / 25$ & 1.65 & 3943 & 0.04 & 1.76 \\
\hline \multicolumn{10}{|l|}{67016} \\
\hline ,383 B & $\mathrm{FeAN}$ & 3865 & 23 & 100.0 & $18 / 18$ & 1.18 & 3868 & & 0.86 \\
\hline, $383 \mathrm{C}$ & & 3866 & 18 & 82.9 & $16 / 24$ & 0.80 & 3884 & & 1.61 \\
\hline, $384 X$ B & $\mathrm{NaAN}$ & 3842 & 19 & 62.9 & $15 / 25$ & 1.45 & 3795 & 0.08 & 1.19 \\
\hline ,384X C & & 3875 & 20 & 60.8 & $22 / 32$ & 2.47 & 3812 & 0.08 & 2.00 \\
\hline ,384Y B & MBX & 4173 & 25 & 64.3 & $9 / 29$ & 1.73 & 4133 & & 1.71 \\
\hline, $385 \mathrm{~B}^{*}$ & & 4044 & 29 & 78.8 & $22 / 29$ & $(4.75)$ & 4010 & & \\
\hline, $385 \mathrm{C}$ & & 4029 & 24 & 67.7 & $20 / 31$ & 1.77 & 4002 & 0.07 & 1.66 \\
\hline, $386 \mathrm{~B}$ & MBX & 4106 & 19 & 58.7 & $11 / 28$ & 2.11 & 4102 & 0.05 & 1.43 \\
\hline, $386 \mathrm{~B}^{*}$ & & 4421 & 43 & 7.5 & $2 / 28$ & 0.09 & 4102 & & \\
\hline ,386 C & & 4093 & 14 & 61.1 & $18 / 35$ & 1.20 & 4077 & 0.05 & 1.97 \\
\hline, $386 \mathrm{C}^{*}$ & & 4216 & 20 & 12.4 & $5 / 35$ & 0.76 & 4077 & & \\
\hline, $387 \mathrm{~B}$ & MBX & 4188 & 20 & 36.3 & $6 / 30$ & 2.47 & 4149 & 0.07 & 1.37 \\
\hline, $387 \mathrm{~B}^{*}$ & & 4444 & 30 & 12.3 & $6 / 30$ & 1.62 & 4149 & & \\
\hline, $387 \mathrm{C}$ & & 4163 & 20 & 52 & $12 / 51$ & $(2.89)$ & 4164 & 0.07 & 3.70 \\
\hline, $387 \mathrm{C}^{*}$ & & 4523 & 62 & 2.8 & $12 / 51$ & (2.77) & 4164 & & \\
\hline, $388 \mathrm{~B}$ & MBX & 4130 & 33 & 47.7 & $8 / 28$ & (4.73) & 4096 & & \\
\hline, $388 \mathrm{~B}^{*}$ & & 4363 & 40 & 11.0 & $5 / 28$ & 1.71 & 4096 & 0.06 & 1.56 \\
\hline ,388 C & & 4131 & 22 & 42.8 & $10 / 25$ & 2.10 & 4101 & & \\
\hline, $388 \mathrm{C}^{*}$ & & 4311 & 46 & 9.5 & $4 / 25$ & 1.46 & 4101 & 0.06 & 1.51 \\
\hline, $389 \mathrm{C}$ & & 4182 & 38 & 32.8 & $9 / 30$ & $(3.48)$ & 4119 & & \\
\hline, $389 \mathrm{C}^{*}$ & & 4370 & 32 & 13.1 & $7 / 30$ & 0.50 & 4119 & & 2.17 \\
\hline, $390 \mathrm{~B}$ & GRAN & 3868 & 24 & 58.2 & $10 / 25$ & $(3.04)$ & 3853 & 0.16 & 2.20 \\
\hline, $390 \mathrm{C}$ & & 3872 & 23 & 61.8 & $8 / 16$ & 1.29 & 3851 & 0.16 & 2.36 \\
\hline ,391 B & $\mathrm{AN}$ & 3848 & 35 & 75.4 & $11 / 16$ & 1.88 & 3807 & & 1.51 \\
\hline, $392 \mathrm{~B}$ & MBX & 4032 & 23 & 84.0 & $12 / 17$ & 1.75 & 4024 & 0.01 & 1.06 \\
\hline, $393 \mathrm{~B}$ & MBX & 4222 & 25 & 28.4 & $6 / 32$ & 1.89 & 4023 & & 2.12 \\
\hline, $393 \mathrm{D}$ & & 4118 & 32 & 80.8 & $13 / 21$ & 1.97 & 4093 & & 1.00 \\
\hline, $393 \mathrm{D}^{*}$ & & 4131 & 29 & 64.9 & $7 / 21$ & 1.42 & 4093 & & \\
\hline
\end{tabular}

MSWD is an $F$-statistic that compares the variability of step ages about their weighted mean with the individual step variances. Samples irradiated at OSU TRIGA reactor at $1 \mathrm{MW}$ for $300 \mathrm{~h}$. Neutron flux measured using Mmhb-1 hornblende (513.9 Ma).

* Alternate plateau based on high-T steps. $\mathrm{K}_{2} \mathrm{O}$ calculated from ICPMS data (Table 2). Lithologies same as Table 1.

A younger emplacement age for the Cayley Plains to accommodate the aluminous melt breccias would decouple deposition of the Cayley and Descartes units. This would imply an age of $\leqslant 3.77 \mathrm{Ga}$ for the Imbrium basin, and would place the Descartes breccias stratigraphically in the interval between Serenitatis and Imbrium. This scenario suggests a local origin for the Descartes breccias as the other basins in this interval (Hertzsprung, Sikorsky-Rittenhouse, Bailly) are located either in the Farside Highlands Terrane or within the South-Pole Aitken basin, and are unlikely candidates as sources of the Descartes breccias. A local origin for the Descartes breccias was advocated by earlier studies that emphasized analogies with terrestrial suevite (Norman, 1981; James, 1981). We tend to discount this possibility, however, because hummocky units morphologically similar to the Descartes units seem to be associated uniquely with lunar basins rather than with $50-100 \mathrm{~km}$ diameter craters such as those present in the vicinity of the Apollo 16 landing site (Spudis, 1993).

Another possibility is that the Descartes breccias represent local, pre-Imbrium deposits that were heated and efficiently outgassed by a thermal event associated with emplacement of Imbrium ejecta. Models of basin ejecta suggest that most of the material in distal deposits is locally derived (Morrison and Oberbeck, 1975; Warren et al., 1996), although the proportion and physical state of distal vs. locally entrained material is not tightly constrained (Korotev, 1997). Further modeling and groundtruthing of these models are required but reheating of predominantly local material by secondary cratering seems an unlikely 


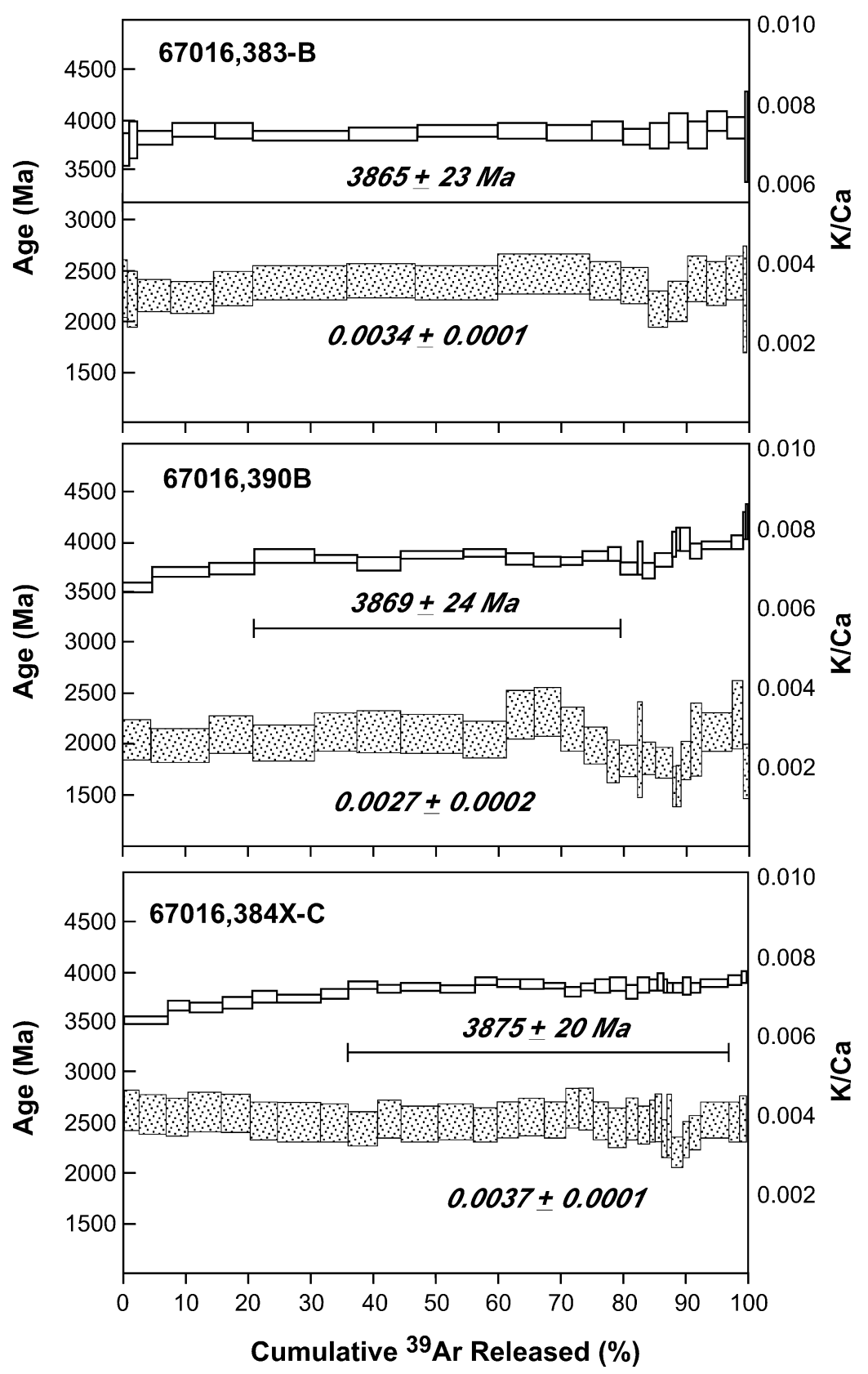

Fig. 3. Argon step-release patterns for anorthositic clasts from 67016. Age steps are shown in open boxes and the corresponding K/Ca shown in stippled boxes. Plateau intervals are indicated by the horizontal bars.

explanation for the age and compositional relationships observed in the Descartes breccias considering their shallow depths prior to excavation by North Ray crater $(\leqslant 200 \mathrm{~m}$; Ulrich, 1973) and the general lack of vertical mixing at the Apollo 16 site over the past 3.8 Ga (Korotev, 1997).

\subsection{Inherited ages in the Descartes breccias}

The intermediate-T plateau ages and high-T inherited component ages obtained from 67016 melt breccia clasts and many of the North Ray crater regolith fragments are older than the inferred assembly age of the breccias. If these breccias were deposited in a single event, as implied by their coherent petrography and geochemistry (James, 1981), then these older ages must reflect incomplete equilibration of the $\mathrm{K}$-Ar system during deposition and inheritance of older age components into the breccias.

High-T components in melt breccia clasts from 67016 have apparent ages ranging up to $4.4-4.5 \mathrm{Ga}$ (Table 4 and Figs. 6-9). These high-T steps tend to have systematically lower K/Ca (Figs. 6 and 8; see also Electronic Annex files 'Annex A-Plateau.pdf' and 'Annex B-Ar Data.xls'), suggesting that relict plagioclase fragments probably derived from lithologies similar to ferroan anorthosite are the likely carriers of this older, undegassed component. The four oldest high-T alternate 'plateaus' from 67016 melt 


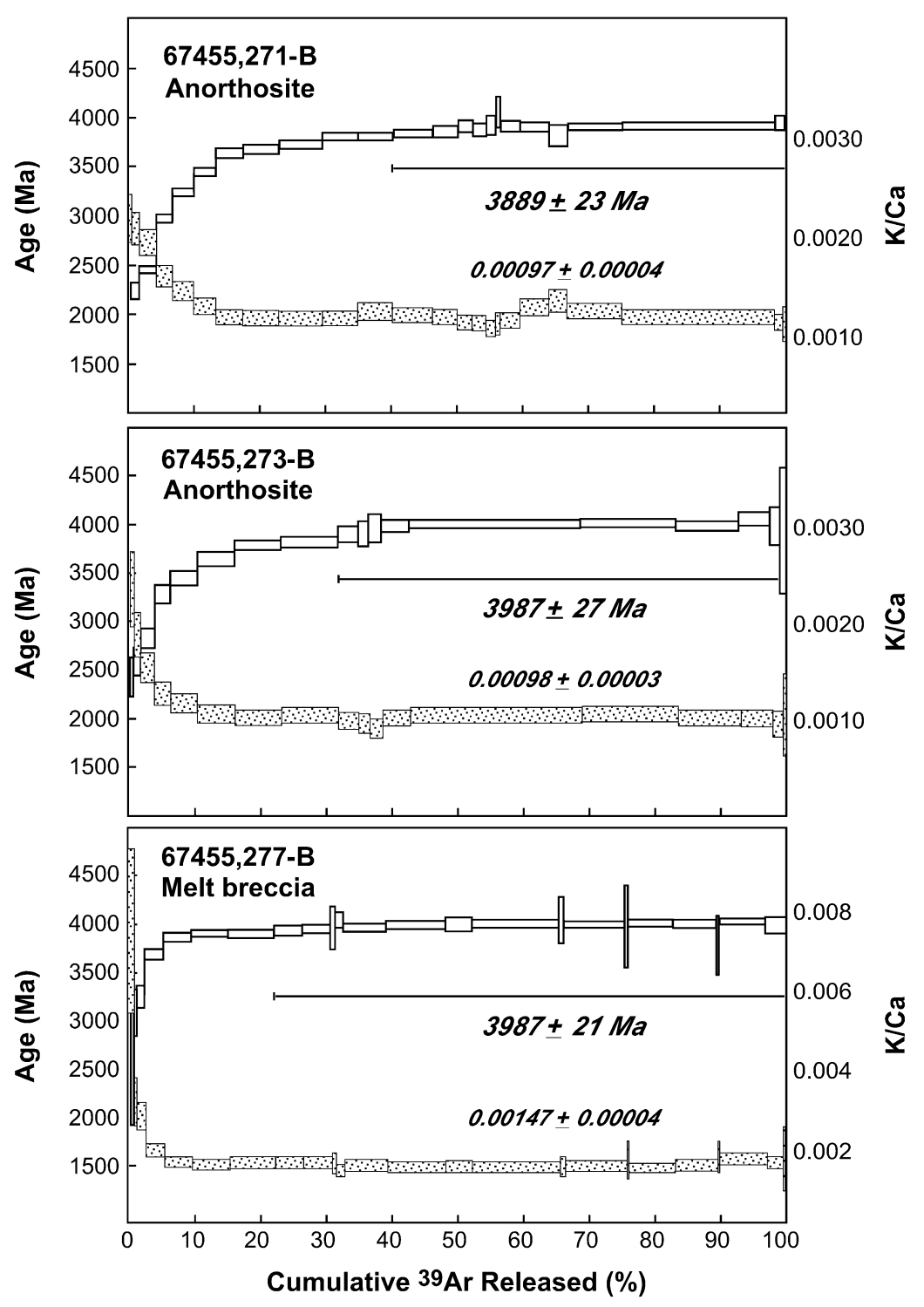

Fig. 4. Argon step-release patterns for anorthositic and melt breccia clasts from 67455. Note consistent evidence for disturbance in low-T steps. Legend same as Fig. 3.

breccia clasts yield a weighted mean of about $4450 \mathrm{Ma}$ (Fig. 9), similar to the igneous crystallization age of lunar ferroan anorthosites inferred from their ${ }^{147} \mathrm{Sm}_{-}-{ }^{143} \mathrm{Nd}$ isotopic compositions (Norman et al., 2003). As two of the four ferroan noritic anorthosites that have been dated by $\mathrm{Sm}-$ $\mathrm{Nd}$ mineral isochrons were extracted from North Ray crater breccias (Alibert et al., 1994; Norman et al., 2003), it is clear that ancient primary igneous crust must have been present in the target lithologies contributing to the Descartes breccias. The petrology and geochemistry of igneous ferroan anorthositic fragments extracted from North Ray crater regolith (Jolliff and Haskin, 1995) and the Descartes breccias (Norman et al., 1991, 1995, 2003) indicates a shallow origin within the lunar crust, but the preservation of near-primary ages in the high-T steps of the 67016 melt breccia clasts implies that this crust was not completely outgassed prior to incorporation into the Descartes breccias.
Notable in the combined data sets from Maurer et al. (1978) and this study is the continuous range of intermediate-T apparent plateau ages from 3.83 to $4.37 \mathrm{Ga}$ (Fig. 9). The previous results of Maurer et al. on regolith fragments implied a bimodal distribution of ages within this range, leading to their distinction of Group $1(4.1-4.2 \mathrm{Ga})$ and Group 2 (3.83-3.96 Ga). Our data on the 67016 and 67455 clasts fills the notional gap in ages between these two groups such that there is no longer an obvious division. The significance of this continuous array of ages is speculative, but we believe the most likely explanation is variable degassing of older material, including fragments of original lunar crust, at the time of the Descartes terrain assembly (3863-3869 Ma). An example of this history is shown in Fig. 8, for sample 67016,389B. The 5 lowest-T steps provide an estimate of the final heating age of $3880 \pm 37 \mathrm{Ma}$, compatible with the Descartes breccia assembly age. Step ages 


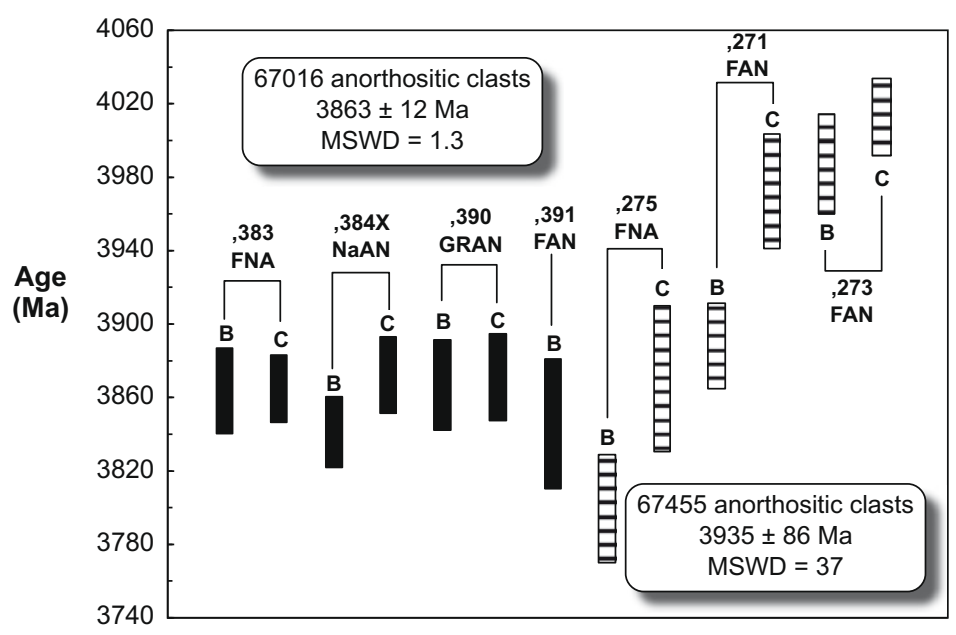

Fig. 5. Weighted mean ages of anorthositic clasts from 67016 and 67455 based on replicate analyses. Legend: FNA, ferroan noritic anorthosite; NaAN, sodic anorthosite; GRAN, granulitic breccia; FAN, mafic-poor ferroan anorthosite. Data from Table 4. Diagram and calculation prepared using ISOPLOT (Ludwig, 1999).

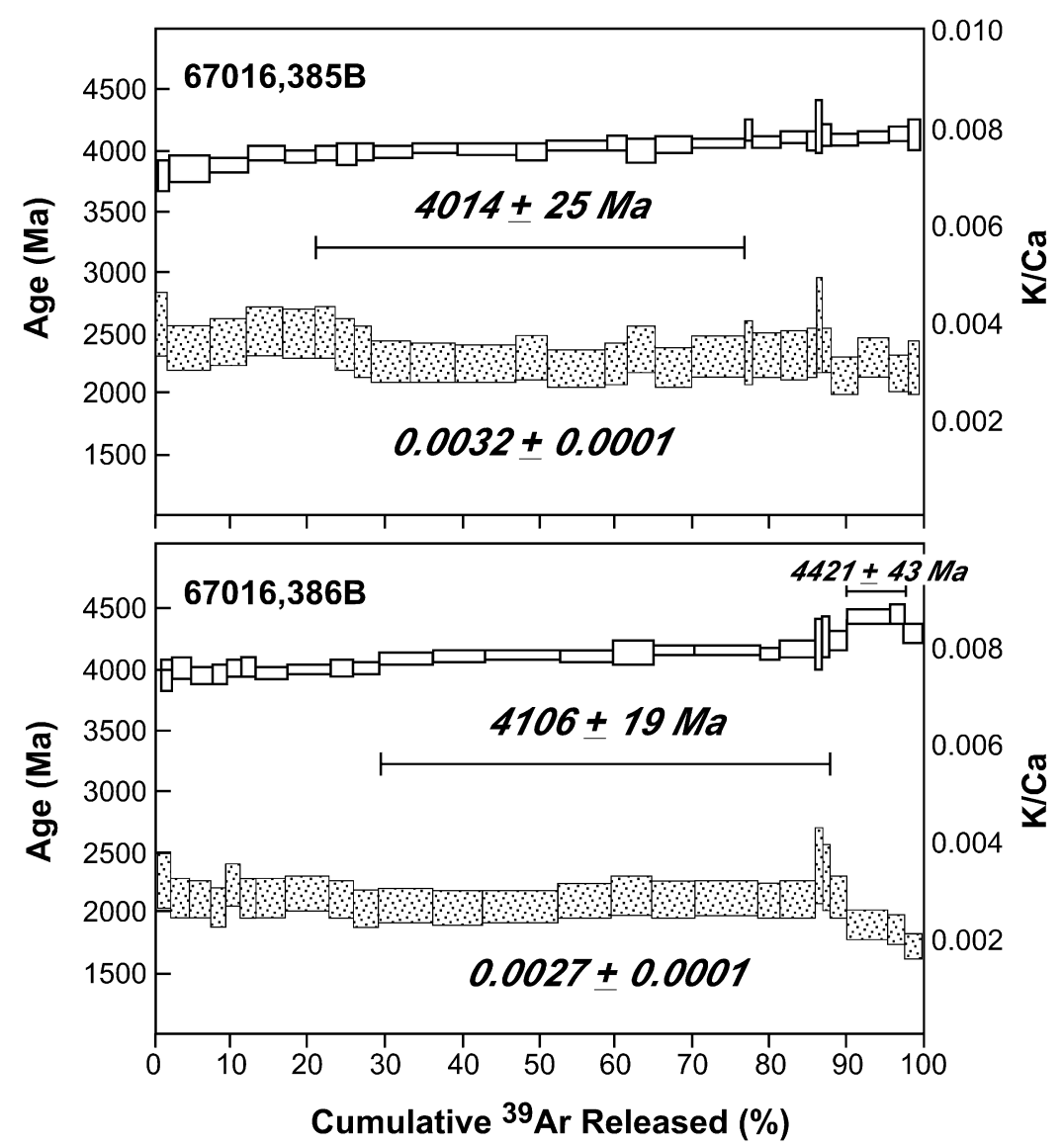

Fig. 6. Argon step-release patterns for melt breccia clasts from 67016. Note older ages in high-T steps from clast,386B. Legend same as Fig. 3.

rise smoothly with increasing temperature to about $84 \%$ of the total gas release. We have calculated a nominal intermediate-T plateau of $4168 \pm 35 \mathrm{Ma}$, which has a MSWD of 2.73 , indicating that the variability in step ages is larger than would be expected from the variance of individual step age measurements, and therefore not an acceptable formation age. At high-T, step ages then rise sharply to a mean of $4450 \pm 39 \mathrm{Ma}$, indicating some largely undegassed feldspar clasts. The smoothly rising part of this age spectrum fits reasonably well with a model of $\sim 85 \%$ diffusive argon loss 


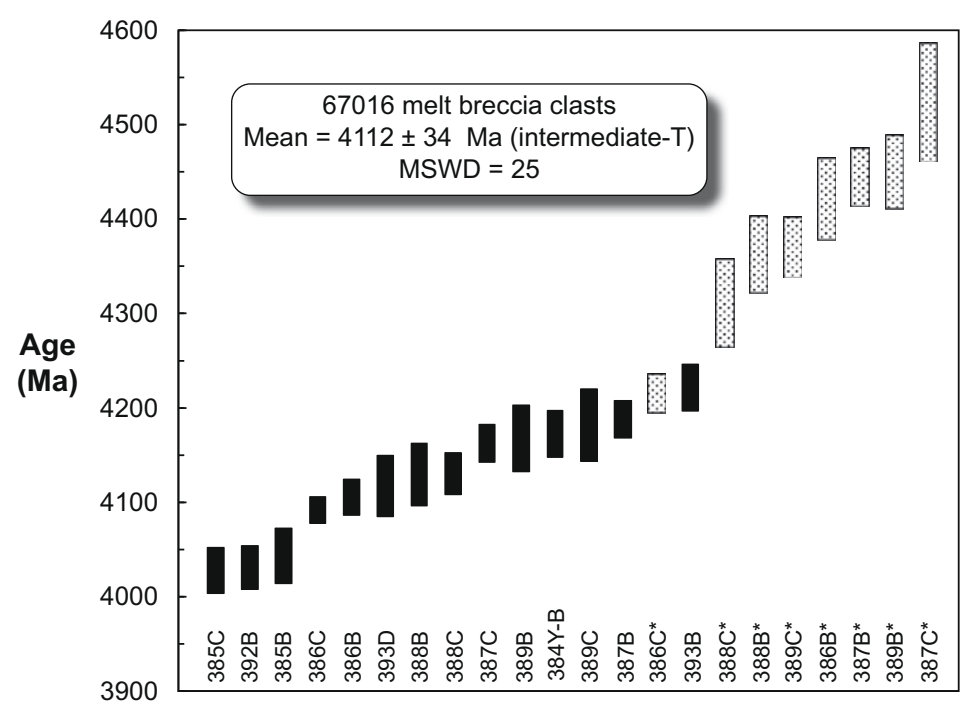

Fig. 7. Replicate ${ }^{40} \mathrm{Ar}-{ }^{39} \mathrm{Ar}$ plateau ages of melt breccia clasts from 67016 arranged according to increasing age. Split numbers for the samples are given across the lower axis. Solid bars represent intermediate-T plateau ages; stippled bars represent alternative ages based on high-T steps. Diagram and calculation prepared using ISOPLOT (Ludwig, 1999).

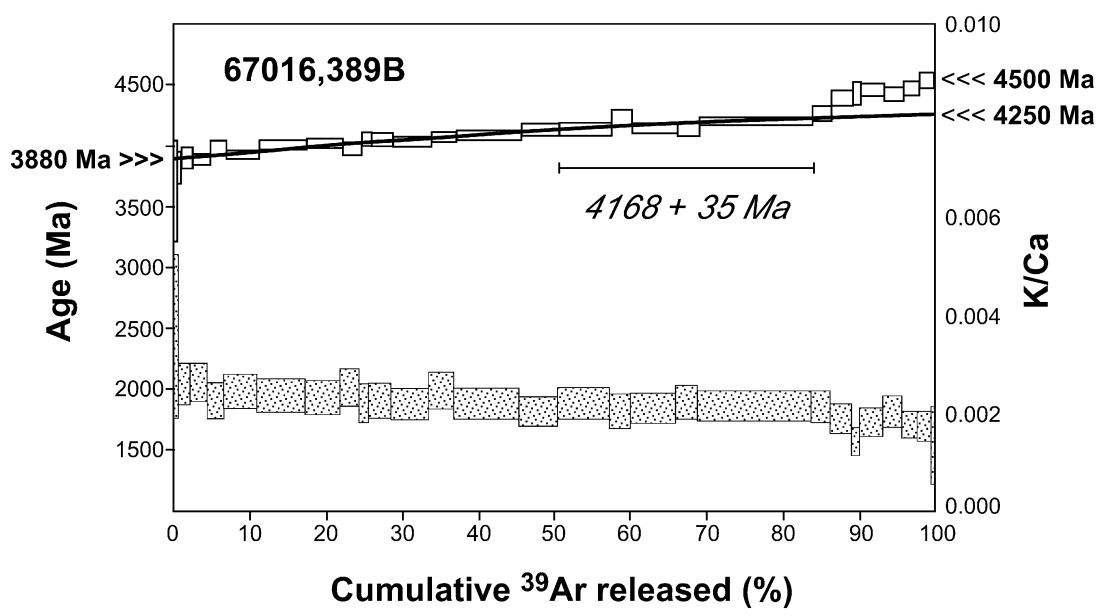

Fig. 8. Age spectrum (black boxes) and K/Ca spectrum (blue boxes) for melt breccia clast 67016,389B. Step ages rise smoothly with temperature from a low- $\mathrm{T}$ intercept at $3880 \pm 37 \mathrm{Ma}$ (weighted mean of first 5 steps) to about $84 \%$ of total gas released, when an abrupt increase to ages of 4.4-4.5 Ga occurs. A nominal weighted mean of middle-T step ages is shown, but the MSWD is larger than acceptable for a plateau age. Instead, the smoothly rising part of the spectrum is well modeled by about $85 \%$ diffusive gas loss from $4.5 \mathrm{Ga}$ lunar crust of uniform grain size, heated at $3.88 \mathrm{Ga}$ (Turner, 1968). The high-T older steps are probably due to larger, feldspathic clasts that have not degassed to the same extent. These steps arise from slightly more anorthitic material, as seen in the lower K/Ca compositions.

from a melt breccia clast with uniform distribution of grain sizes and initial age of $4.5 \mathrm{Ga}$, re-heated at $3.88 \mathrm{Ga}$ (Turner, 1968).

These intermediate ages may also record (perhaps imperfectly) previous thermal events affecting the ancient lunar crust. Several samples have acceptable plateau ages (according to the MSWD criteria) around 4.1 Ga (Figs. 6, 7 and 9 and Table 4), corresponding to Maurer et al.'s Group 1. Mean ages for this cluster range from about 4.11 to $4.13 \mathrm{Ga}$ depending on the specific samples included in the calculation (Fig. 9). Maurer et al. (1978) proposed that these ages reflect cratering events somewhat smaller than basins (up to a few hundred $\mathrm{km}$ diameter). This inter- pretation was based on the low $\mathrm{K}$ contents of these fragments (100-400 ppm) and the assumption that the lunar crust is compositionally stratified with an anorthositic upper crust overlying a more mafic and KREEP-rich lower crust. In light of current knowledge about the regional distribution of near-surface KREEP (Jolliff et al., 2000), this distinction in depth and crater size no longer seems viable, and older basin-forming impacts into KREEP-poor, anorthositic crust can be considered as a realistic possibility.

Intriguing hints of sizable impacts on the Moon at about this time are not uncommon in the lunar record. Peak metamorphic ages of 4.1-4.2 Ga have been inferred from the ${ }^{40} \mathrm{Ar}-{ }^{39} \mathrm{Ar}$ compositions of several lunar granulitic breccias, 


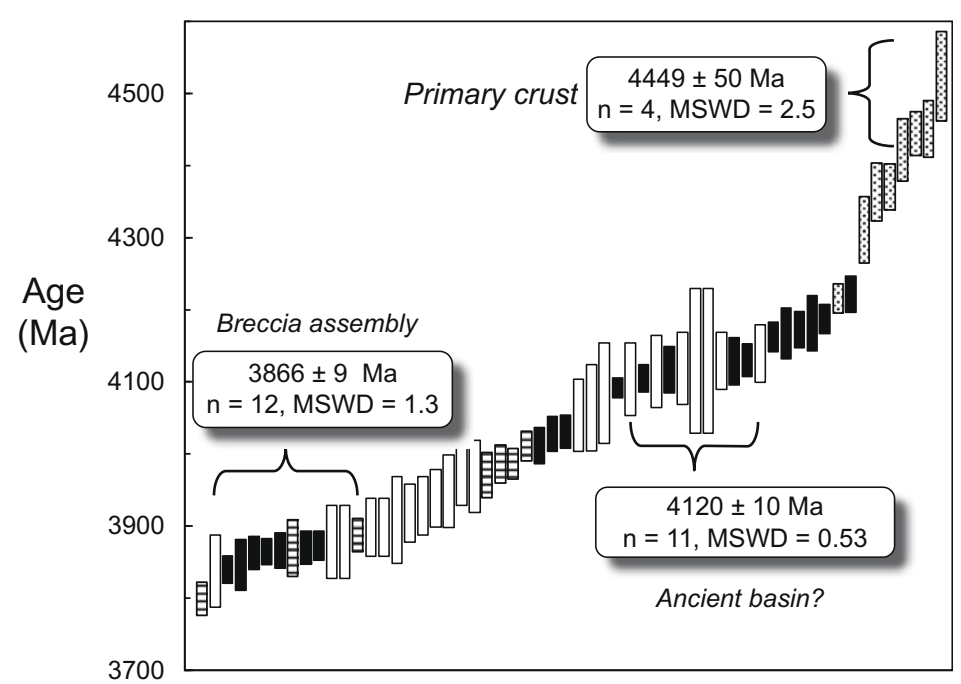

Fig. 9. Summary diagram showing ${ }^{40} \mathrm{Ar}-{ }^{39} \mathrm{Ar}$ plateau ages of anorthositic and melt breccia clasts from 67016 (solid black bars) and 67455 (horizontal stripes) compared to those obtained on North Ray crater regolith fragments by Maurer et al. (1978) (open bars). Ages inferred from high-T steps on the 67016 melt breccia clasts are shown as stippled bars (cf. Fig. 7). An assembly age of $3866 \pm 9$ Ma age for the Descartes fragmental breccias is proposed based on the youngest group of ages. Ages inferred from the highest-T steps of the 67016 melt breccia fragments correspond to igneous crystallization ages of lunar anorthosites (Norman et al., 2003). More speculative is the significance of the cluster of ages around $4.1 \mathrm{Ga}$. This could be dating an older impact or other thermal event in the source region of the Descartes breccias, or it could be an artifact of breccia emplacement.

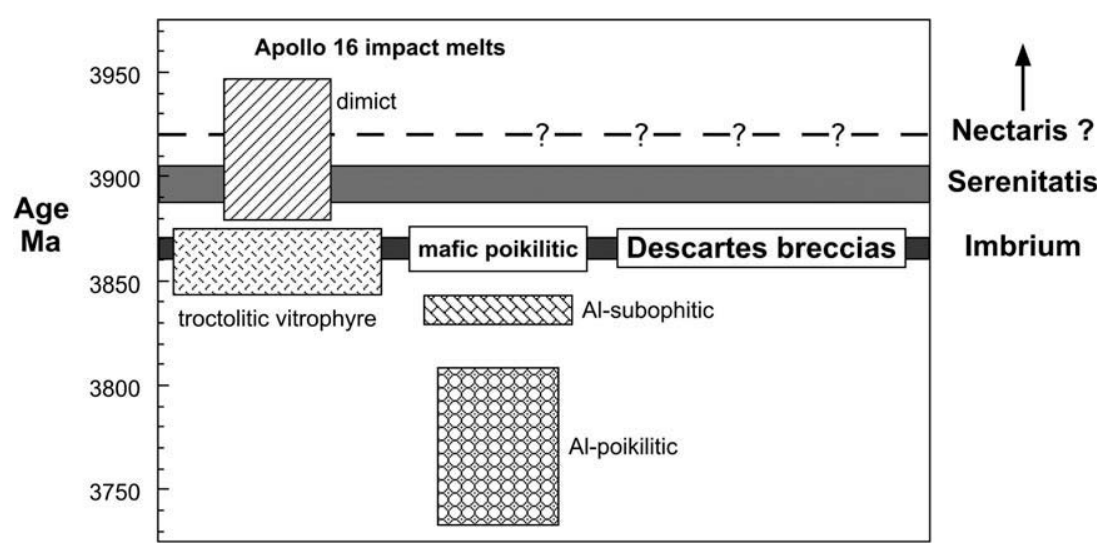

Fig. 10. A summary of emplacement and crystallization ages of the Descartes fragmental breccias (this study) and Apollo 16 impact melt rocks grouped by their texture (Norman et al., 2006) compared with previously proposed ages of the Imbrium (Dalrymple and Ryder, 1993), Serenitatis (Dalrymple and Ryder, 1996), and Nectaris (James, 1981; Stöffler and Ryder, 2001) basins. The vertical width of the boxes and stippled bands indicates the $2 \sigma$ uncertainty on these ages. The age of the Descartes breccias is identical with that of the KREEP-rich, maficpoikilitic impact melt rocks, which are a defining component of the Apollo 16 Cayley formation (Korotev, 1997). The Descartes and Cayley formations both appear to be facies of Imbrium ejecta. There is no obvious clustering of ages obtained from the Descartes breccias that supports an age of $3.92 \mathrm{Ga}$ for Nectaris (see also Fig. 9). Older ages obtained from the dimict breccias may be suspect (see text). Recalibration of the ${ }^{40} \mathrm{Ar}-{ }^{39} \mathrm{Ar}$ flux monitor would shift all of these ages by a constant proportion but would not change the relative relationships.

including a number of recrystallized 'anorthositic gabbro' clasts extracted from Serenitatis impact melt breccia 73215 (Turner and Cadogan, 1975; Schaeffer et al., 1976; Jessberger et al., 1977; Warner et al., 1977; Delano and Bence, 1977; Hudgins et al., 2008). Pidgeon et al. (2007) and Grange et al. (2009) dated zones of brecciated and recrystallized zircon in lunar breccias 73235 and 73217 at $4.19 \pm 0.01 \mathrm{Ga}$ and $4.34 \pm 0.01 \mathrm{Ga}$, respectively and ascribed those ages to major impact events. A ${ }^{147} \mathrm{Sm}-{ }^{144} \mathrm{Nd}$ mineral isochron on coarse-grained crystalline breccia
67955 (also collected at North Ray crater) was interpreted as dating a large impact event at $4.20 \pm 0.07 \mathrm{Ga}$ (Norman et al., 2007). It seems possible, but difficult to prove, that the $\sim 4.1 \mathrm{Ga}$ ages obtained from the Descartes melt breccia clasts are dating one or more real but now cryptic impact events affecting the ancient lunar crust (James, 1981).

The continuous array of ${ }^{40} \mathrm{Ar}-{ }^{39} \mathrm{Ar}$ ages obtained from the Descartes breccia clasts and the North Ray crater regolith fragments could represent real geological events or variable $\mathrm{Ar}$ loss and age resetting during breccia emplacement. 
Accepting the individual ages at face value could be used as evidence for a quasi-continuous cratering history, perhaps punctuated by larger or more frequent events at $\sim 4.1 \mathrm{Ga}$, or multiple episodes of breccia emplacement. Alternatively, the array may reflect variable resetting of older crustal rocks. Petrographic and geochemical data show that the crustal stratigraphy excavated by the Descartes brecciaforming event included both igneous anorthosites with crystallization ages of $\sim 4.4 \mathrm{Ga}$, and impact breccias, at least some of which formed at $\sim 4.2 \mathrm{Ga}$ (Norman et al., 2003, 2007). Intermediate plateau ages may therefore reflect incomplete equilibration of these older components during deposition of the Descartes breccias at 3.87 Ga and subsequent erosion on the lunar surface by later impacts around 2.0-2.5 Ga.

As many of the older plateau ages come from the fragment-laden melt breccia clasts, it is possible that partial outgassing or mixing of argon from outgassed melt and older clasts produced apparent plateaus that have no age significance (Maurer et al., 1978). The constant K/Ca across most of the 4.1-4.2 Ga incremental heating plateaus, however, suggests that a single phase dominates the release pattern for most of these samples (Figs. 6 and 8; Electronic Annex 1; see also Maurer et al., 1978), arguing against mixing of different age components during analysis. It is curious that the oldest components are preserved preferentially in 67016 melt breccia clasts, whereas the anorthositic clasts in this rock appear to be systematically and reproducibly outgassed. In contrast, the one melt breccia clast from 67455 that we analyzed (,277B) gave a plateau age of $3987 \pm 21 \mathrm{Ma}$ and no particular evidence for older components in the high-T steps (Table 4). Warren et al. (2007) noted petrographic evidence for different degrees of $\mathrm{CaAl}-\mathrm{NaSi}$ equilibration between melt and mineral fragments within a suite of melt breccia rocklets collected from North Ray crater. This raises the possibility that melt breccia clasts in the Descartes breccias may have experienced variable rates of quenching and outgassing during transport and emplacement, with some older components in the mineral fragments being armored against diffusive argon loss by the quenched melt.

\subsection{Relationships to Major Basins and Implications for a Late Heavy Bombardment}

Emplacement of the Descartes breccias at $3866 \pm 9 \mathrm{Ma}$ as inferred from the youngest group of clasts and regolith fragments (Fig. 9) would be coincident with the age of Imbrium obtained from Apollo 15 melt rocks (3865 $\pm 5 \mathrm{Ma}$; Dalrymple and Ryder, 1993) (Fig. 10). When corrected for recent intercalibrations of flux monitor ages (Baksi et al., 1996; Renne et al., 1998), these ${ }^{40} \mathrm{Ar}-{ }^{39} \mathrm{Ar}$ dates are also identical within error to the U-Pb age of apatite in Apollo 14 breccias (3926 \pm 3 Ma; Nemchin et al., in press), consistent with the widespread distribution of Imbrium ejecta on the nearside of the Moon and considerable lateral variations in the composition and source of this ejecta. This age for Imbrium is resolvably younger than that than proposed for Serenitatis based on ${ }^{40} \mathrm{Ar}-{ }^{39} \mathrm{Ar}$ dates of Apollo 17 poikilitic breccias $(3893 \pm 9 \mathrm{Ma}$; Dalrymple and Ryder, 1996) (Fig. 10). As Nectaris is stratigraphically older than Serenitatis, this precludes the possibility that Descartes breccias are primary Nectaris ejecta as advocated by James (1981) and Stöffler et al. (1981, 1985). Geochemical and petrographic characteristics indicating the presence of KREEP and Mg-suite components in these breccias (Fig. 2) also point toward a provenance in the Procellarum-KREEP Terrane. Together the ages and compositions of the Descartes breccias strongly favor an origin as Imbrium ejecta.

Correlating the Descartes breccias with Imbrium implies that there is now no direct control on the absolute age of the Nectaris basin. Previous inferences of $3.92 \mathrm{Ga}$ for the age of Nectaris, implying an age difference of only $\sim 55 \mathrm{Ma}$ between Nectaris and Imbrium, cited the apparent bimodal distribution of ages in North Ray crater regolith fragments (Maurer et al., 1978) and geologic interpretations of the Descartes breccias based on cratering models and physiographic analogues with the Orientale basin (James, 1981; Stöffler and Ryder, 2001). With the addition of our new data it is clear that there is a continuous range of apparent plateau ages from 3.86 through to at least $4.37 \mathrm{Ga}$, probably resulting from variable age resetting at the time of the Descartes assembly, with no apparent clustering at $3.92 \mathrm{Ga}$ (Fig. 9). From the current data set we see no particular evidence for a dominant regional event at that time, and no compelling reason to ascribe that age to Nectaris.

In this interpretation, the geology of the Apollo 16 site is dominated by the Imbrium event, a view promoted by USGS photogeologists based on transitional contacts between Cayley and Descartes units, and the lack of Imbrium sculpture on both of these units (Muehlberger et al., 1972, 1980; Hodges et al., 1973; Ulrich, 1973). This conclusion has considerable significance for the interpretation of lunar basin ages and the terminal cataclysm hypothesis. Mass flux curves such at the one presented by Ryder (2002) depend critically on an assumed age of $\sim 3.9$ Ga for Nectaris to create a sharp rise in the accretion rate at this time. In addition, crater density populations on the large lunar basin deposits and dynamical evolution models tend to favor a late increase in mass flux if Nectaris is $\leqslant 4 \mathrm{Ga}$, but provide little support for a late cataclysm if Nectaris is as old as 4.1-4.2 Ga (Bottke et al., 2007; Norman and Lineweaver, 2008; Norman, 2009). The age of Nectaris appears to be effectively unconstrained by the sample data. Some lunar samples from Apollo 16 or conceivably from the Apollo 11 site might be Nectaris ejecta but they have so far not been tied convincingly to that basin.

Inheritance of undegassed components with ages of up to $4.4-4.5 \mathrm{Ga}$ in the melt breccia clasts shows that the near-surface crustal target lithologies that became incorporated into these breccias had not been completely outgassed prior to the Imbrium event. This may favor a late increase in cratering intensity, or simply reflect the magnitude of the Imbrium event compared to previous impacts in the region. A robust test of the late cataclysm hypothesis will require an accurate absolute age for one or more of the older lunar basins. The South-Pole Aitken basin (SPA) is stratigraphically one of, if not the, oldest basin on the Moon, but its age would provide strong evidence for a late heavy 
bombardment only if it is very young (i.e., $\sim 4 \mathrm{Ga}$; Norman and Lineweaver, 2008; Norman, 2009). Ages of 4.2-4.4 Ga for SPA would anchor the integrated cratering curve but would not be a definitive test of the late heavy bombardment scenario. Alternatively, a stratigraphically intermediate basin such as Nectaris may provide a more diagnostic test of the cataclysm. The Australe, Ingenii, Poincare, Planck, and Apollo basins are all pre-Nectarian and they occur within or proximal to SPA. These basins may be attractive exploration targets if a South-Pole lunar outpost proceeds. Quantitative ages for any of these basins would vastly improve our understanding of the impact history of the lunar crust and the early Earth, and provide a useful test of the late heavy bombardment hypothesis.

\section{CONCLUSIONS}

${ }^{40} \mathrm{Ar}-{ }^{39} \mathrm{Ar}$ ages and major + trace element compositions of anorthositic and melt breccia clasts extracted from lunar breccias 67016 and 67455 provide new constraints on the origin of the feldspathic fragmental breccias collected at North Ray crater, Apollo 16. Replicate incremental heating experiments on anorthositic clasts from 67016 yielded welldefined ${ }^{40} \mathrm{Ar}-{ }^{39} \mathrm{Ar}$ plateaus that define a narrow range of ages (3842-3875 Ma) and little evidence of younger disturbance or older inherited components. ${ }^{40} \mathrm{Ar}-{ }^{39} \mathrm{Ar}$ compositions of anorthositic clasts from breccia 67455 are broadly consistent with the results for 67016 , but show some incomplete resetting from an earlier formation age, and clear evidence for later (2.0-2.5 Ga) heating disturbance in their release spectra. A group of anorthositic clasts from 67016 and 67455 and three North Ray crater regolith fragments dated by Maurer et al. (1978) defines a weighted mean age of $3866 \pm 9 \mathrm{Ma}$. We interpret this as the emplacement age of the feldspathic fragmental breccias. While clast-poor melt breccias are usually considered to be the best candidates for dating lunar impact events, our results imply that fragmental breccias can also provide useful ages under appropriate circumstances.

Major and trace element compositions are consistent with deposition of the Descartes breccias as a coherent lithologic unit, and their regional distribution suggests emplacement as basin ejecta. Geochemical and petrologic signatures identify KREEP and/or Mg-suite lithologies in these breccias, pointing toward a provenance in the Procellarum-KREEP Terrane. The combination of age and geochemical constraints favors emplacement of the Descartes breccias by the Imbrium event and appears to rule out an origin for these breccias as ejecta from the older Nectaris basin. In this interpretation, the Cayley and Descartes units of the central nearside highlands are both ejecta facies from the Imbrium basin. Differences in bulk composition between the Cayley and Descartes units may reflect pre-impact stratigraphy or lateral heterogeneity in the lunar crust, and the processes of basin ejecta deposition.

${ }^{40} \mathrm{Ar}-{ }^{39} \mathrm{Ar}$ plateau ages ranging from 4014 to $4188 \mathrm{Ma}$, and evidence for even older (to $\geqslant 4.4 \mathrm{Ga}$ ) components in some high-T steps were obtained from the 67016 melt breccia clasts. We interpret these older ages predominantly as inheritance due to incomplete degassing of the melt breccia clasts. A cluster of ages $\sim 4.1 \mathrm{Ga}$, evident in the combined dataset from this study and that of Maurer et al. (1978), may represent ancient impacts or incomplete degassing of primary igneous crust. We see no compelling reason to assign an age of 3.92 Ga to the Nectaris basin (James, 1981; Stöffler and Ryder, 2001). There is a continuous range of plateau-like ages from 3.86 through to at least $4.37 \mathrm{Ga}$ in the North Ray crater regolith fragments and the 67016 and 67455 clasts, with no clustering at $3.92 \mathrm{Ga}$. The age of Nectaris appears to be unconstrained by the sample data.

Inheritance of undegassed components with ages of up to $4.5-4.5 \mathrm{Ga}$ in the 67016 melt breccia clasts shows that the near-surface crustal target lithologies that were incorporated into these breccias had not been completely outgassed prior to the Imbrium event. This may favor a late increase in cratering intensity, but a robust test of the cataclysm hypothesis will require an accurate definition of the absolute age of Nectaris or one of the stratigraphically intermediate pre-Nectarian lunar basins. Several such basins occur in the vicinity of South-Pole Aitken, and may be attractive exploration targets to define the pre-3.9 Ga impact history of the lunar crust.

\section{ACKNOWLEDGMENTS}

This project was initiated and inspired by Graham Ryder. This research was supported in part by NASA award NAG5-11652 to R.A.D. M.N. gratefully acknowledges the Lunar and Planetary Institute for the support and patience necessary to prepare this manuscript. Conversations with Barbara Cohen, Randy Korotev, Bill Muehlberger, and Paul Spudis helped refine our thoughts. Journal reviews by Audrey Bouvier, Randy Korotev, and two anonymous reviewers, and comments by Ross Taylor are greatly appreciated.

\section{APPENDIX A. SUPPLEMENTARY DATA}

Supplementary data associated with this article can be found, in the online version, at doi:10.1016/j.gca.2009. 10.024 .

\section{REFERENCES}

Alibert C., Norman M. D. and McCulloch M. T. (1994) An ancient $\mathrm{Sm}-\mathrm{Nd}$ age for a ferroan noritic anorthosite clast from lunar breccia 67016. Geochim. Cosmochim. Acta 58, 2921-2926.

Baksi A. K., Archibald D. A. and Farrar E. (1996) Intercalibration of ${ }^{40} \mathrm{Ar} /{ }^{39} \mathrm{Ar}$ dating standards. Chem. Geol. 129, 307-324.

Bottke W. F., Levison H. F., Nesvorn D. and Dones L. (2007) Can planetesimals leftover from terrestrial planet formation produce the lunar late heavy bombardment? Icarus 190, 203-223.

Dalrymple G. B. and Ryder G. (1993) ${ }^{40} \mathrm{Ar} /{ }^{39} \mathrm{Ar}$ age spectra of Apollo 15 impact melt rocks by laser step-heating and their bearing on the history of lunar basin formation. J. Geophys. Res. 98, 13085-13096, doi:10.1029/93JE01222.

Dalrymple G. B. and Ryder G. (1996) Argon-40/argon-39 age spectra of Apollo 17 highlands breccia samples by laser step heating and the age of the Serenitatis basin. J. Geophys. Res. 101, 26069-26084. doi:10.1029/96JE02806.

Delano J. W. and Bence A. E. (1977) 4.2-4.3 AE anorthositic soil fragments: equilibrated or unequilibrated polycomponent systems? Proc. Lunar Sci. Conf. 8, 2029-2050. 
Eggins S. M., Woodhead J. D., Kinsley L. P. J., Mortimer G. E., Sylvester P., McCulloch M. T., Hergt J. M. and Handler M. R. (1997) A simple method for the precise determination of $\geqslant 40$ trace elements in geological samples by ICPMS using enriched isotope internal standardization. Chem. Geol. 134, 311-326.

Govindaraju K. (1994) 1994 compilation of working values and sample description for 383 geostandards. Geostandards Newsletter 18, 1-158.

Grange M. L., Nemchin A. A., Pidgeon R. T., Timms N., Muhling J. R. and Kennedy A. K. (2009) Thermal history recorded by the Apollo 17 impact melt breccia 73217. Geochim. Cosmochim. Acta 73, 3093-3107.

Head J. W. (1974) Stratigraphy of the Descartes region (Apollo 16): implications for the origin of samples. The Moon 11, 77-100.

Hodges C. A., Muehlberger W. R. and Ulrich G. E. (1973) Geologic setting of Apollo 16. Proc. Lunar Sci. Conf. 4, 1-25.

Hohenberg C. M., Marti K., Podosek F. A., Reedy R. C. and Shirck J. R. (1978) Comparison between observed and predicted cosmogenic noble gases in lunar samples. In Lunar Planet. Sci., IX. The Lunar and Planetary Institute, Houston, pp. 2311-2344.

Hudgins J. A., Spray J. G., Kelley S. P., Korotev R. L., Sarah C. and Sherlock S. C. (2008) A laser probe 40Ar/39Ar and INAA investigation of four Apollo granulitic breccias. Geochim. Cosmochim. Acta 72, 5781-5798.

James O. B. (1981) Petrologic and age relations of the Apollo 16 rocks: implications for subsurface geology and the age of the Nectaris basin. Proc. Lunar Planet. Sci. Conf. 12B, 209-233.

Jessberger E. K., Kirsten T. and Staudacher T. (1977) One rock and many ages - further $\mathrm{K}-\mathrm{Ar}$ data on consortium breccia 73215. Proc. Lunar Sci. Conf. 8, 2567-2580.

Jolliff B. L. and Haskin L. A. (1995) Cogenetic rock fragments from a lunar soil: evidence of a ferroan noritic anorthosite pluton on the Moon. Geochim. Cosmochim. Acta 59, 23452374.

Jolliff B. L., Gillis J. J., Haskin L. A., Korotev R. L. and Wieczorek M. A. (2000) Major lunar crustal terranes: surface expressions and crust-mantle origins. J. Geophys. Res. 105, 4197-4416.

Koppers A. A. P., Staudigel H. and Duncan R. A. (2003) Highresolution ${ }^{40} \mathrm{Ar} /{ }^{39} \mathrm{Ar}$ dating of the oldest oceanic basement basalts in the western Pacific basin. Geochem. Geophys. Geosys. 4 (11) 8914. doi:10.1029/2003GC000574.

Korotev R. L. (1994) Compositional variation in Apollo 16 impact melt breccias and inferences for the geology and bombardment history of the central highlands of the Moon. Geochim. Cosmochim. Acta 58, 3931-3969.

Korotev R. L. (1997) Some things we can infer about he Moon from the composition of the Apollo 16 regolith. Meteorit. Planet. Sci. 32, 447-478.

Lanphere M. A., Dalrymple G. B., Fleck R. J. and Pringle M. S. (1990) Intercalibration of mineral standards for $\mathrm{K}-\mathrm{Ar}$ and ${ }^{40} \mathrm{Ar} /{ }^{39} \mathrm{Ar}$ age measurements. EOS, Trans. Am. Geophys. Union 71, 1658.

Lawrence D. J., Feldman W. C., Barraclough B. L., Binder A. B., Elphic R. C., Maurice S., Miller M. C. and Prettyman T. H. (2000) Thorium abundances on the lunar surface. J. Geophys. Res. 105, 20307-20331.

Lindstrom M. M. (1984) Alkali gabbronorite, ultra-KREEPy melt rock and the diverse suite of clasts in North Ray crater feldspathic fragmental breccia 67975. Proc. Lunar Planet. Sci. Conf. 15th, J. Geophys. Res. 89, C50-C62.

Lindstrom M. M. and Salpas P. A. (1981) Geochemical studies of rocks from North Ray Crater, Apollo 16. Proc. Lunar Planet. Sci. Conf. 12B, 305-322.

Lindstrom M. M. and Salpas P. A. (1983) Geochemical studies of feldspathic fragmental breccias and the nature of North Ray
Crater ejecta. Proc. Lunar Planet. Sci. Conf. 13th, J. Geophys. Res. 88, A671-A683.

Lindstrom M. M., Nava D. F., Lindstrom D. J., Winzer S. R., Lum R. K. L., Schuhmann P. J., Schuhmann S. and Philpotts J. A. (1977) Geochemical studies of the White Breccia boulders at North ray crater, Descartes region of the lunar highlands. Proc. Lunar Sci. Conf. 8, 2137-2151.

Ludwig K. R. (1999) Users manual for Isoplot/Ex, version 2.10. A Geochronological Toolkit for Microsoft Excel. Berkeley Geochronology Center Special Publication No. 1a, 2455 Ridge Road, Berkeley, CA 94709, USA.

Marvin U. B. and Lindstrom M. M. (1983) Rock 67015: a feldspathic fragmental breccia with KREEP-rich melt clasts. Proc. Lunar Planet. Sci. Conf. 13th, J. Geophys. Res. 88, A659A670.

Marvin U. B., Lindstrom M. M., Bernatowicz T. J., Podosek F. A. and Sigiura N. (1987) The composition and history of breccia 67015 from North Ray crater. Proc. Lunar Planet. Sci. Conf. 17th, J. Geophys. Res. 92, E471-E490.

Maurer P., Eberhardt P., Geiss J., Grögler N., Stettler A., Brown G. M., Peckett A. and Krähenbühl U. (1978) Pre-Imbrian craters and basins: ages, compositions, and excavation depths of Apollo 16 breccias. Geochim. Cosmochim. Acta 42, 16871720.

Minkin J. A., Thompson C. L. and Chao E. C. T. (1977) Apollo 16 white boulder consortium samples 674554 and 67475: petrologic investigations. Proc. Lunar Sci. Conf. 8, 1967-1986.

Morrison R. H. and Oberbeck V. R. (1975) Geomorphology of crater and basin deposits - emplacement of the Fra Mauro formation. Proc. Lunar Sci. Conf. 6th, 2503-2530.

Muehlberger W. R. et al. (1972) Preliminary geologic investigation of the Apollo landing site. In Apollo 16 Preliminary Science Report. NASA Special Publication 315, pp. 6-1-6-81.

Muehlberger W. R., Hörz F., Sevier J. R. and Ulrich G. E. (1980) Mission objectives for geological exploration of the Apollo 16 landing site. In Proc. Conf. Lunar Highlands Crust (eds. J. J. Papike and R. B. Merrill). Pergamon Press, New York, pp. 1-49.

Nemchin A. A., Pidgeon R. T., Healy D., Grange M. L., Whitehouse M. J. and Vaughan J. (in press) The comparative behaviour of apatite-zircon $\mathrm{U}-\mathrm{Pb}$ systems in Apollo 14 breccias: implications for the thermal history of the Fra Mauro Formation, Meteorit. Planet. Sci.

Nord G. L., Christie J. M., Heuer A. H. and Lally J. S. (1975) North Ray crater breccias: an electron petrographic study. Proc. Lunar Sci. Conf. 6th, 779-797.

Norman M. D. (1981) Petrology of suevitic lunar breccia 67016. Proc. Lunar Planet. Sci. Conf. 12, 235-252.

Norman M. D. (2009) The lunar cataclysm: reality or mythconception? Elements 5, 23-28.

Norman M. D. and Lineweaver C. H. (2008) New Perspectives on the Lunar Cataclysm from Pre-4 Ga Impact Melt Breccia and Cratering Density Populations. In Proceedings of the Seventh Australian Space Science Conference (eds. Wayne Short and Iver Cairns) National Space Society of Australia, Sydney, pp. 73-83. ISBN 13: 978-0-9775740-1-8.

Norman M. D. and Ryder G. (1980) Geochemical constraints on the igneous evolution of the lunar crust. Proc. Lunar Planet. Sci. Conf. 11, 317-333.

Norman M. D. and Taylor S. R. (1992) Geochemistry of lunar crustal rocks from breccia 67016 and the composition of the Moon. Geochim. Cosmochim. Acta 56, 1013-1024.

Norman M., Borg L., Nyquist L. and Bogard D. (2003) Chronology, geochemistry, and petrology of a ferroan noritic anorthosite clast from Descartes breccia 67215: clues to the age, origin, structure, and impact history of the lunar crust. Meteorit. Planet. Sci. 38, 645-661. 
Norman M. D., Duncan R. A. and Huard J. J. (2006) Identifying impact events within the lunar cataclysm from ${ }^{40} \mathrm{Ar}-{ }^{39} \mathrm{Ar}$ ages and compositions of Apollo 16 impact melt rocks. Geochim. Cosmochim. Acta 70, 6032-6049.

Norman M. D., Keil K., Griffin W. L. and Ryan C. G. (1995) Fragments of ancient lunar crust: petrology and geochemistry of ferroan noritic anorthosites from the Descartes region of the Moon. Geochim. Cosmochim. Acta 59, 831-847.

Norman M. D., Griffin W. L., Pearson N. J., Garcia M. O. and O'Reilly S. Y. (1998) Quantitative analysis of trace element abundances in glasses and minerals: a comparison of laser ablation ICPMS, solution ICPMS, proton microprobe, and electron microprobe data. J. Anal. Atom. Spec. 13, 477-482.

Norman M. D., Shih C.-Y., Nyquist L. E., Bogard D. D. and Taylor L. A. (2007) Early impacts on the Moon: crystallization ages of Apollo 16 melt breccias. Lunar Planet. Sci., vol. 38. The Lunar and Planetary Institute, Houston. \#1991 (abstr.)

Norman M. D., Taylor G. J. and Keil K. (1991) Additional complexity in the lunar crust: petrology of sodic anorthosites and sulfur-rich, ferroan noritic anorthosites. Geophys. Res. Lett. 18, 2081-2084.

Pfänder J. A., Münker C., Stracke A. and Mezger K. (2007) Nb/Ta and $\mathrm{Zr} / \mathrm{Hf}$ in ocean island basalts - implications for crustmantle differentiation and the fate of niobium. Earth Planet. Sci. Lett. 254, 158-172.

Pidgeon R. T., Nemchin A. A., van Bronswijk W., Geisler T., Meyer C., Compston W. and Williams I. S. (2007) Complex history of a zircon aggregate from lunar breccia 73235 . Geochim. Cosmochim. Acta 71, 1370-1381.

Raczek I., Stoll B., Hofmann A. W. and Jochum K. P. (2001) Highprecision trace element data for the USGS reference materials BCR-1, BCR-2, BHVO-1, BHVO-2, AGV-1. AGV-2, DTS-1, DTS-2, GSP-1, and GSP-2 by ID-TIMS and MIC-SSMS. Geostandards Newsletter 25, 77-86.

Renne P. R., Swisher C. C., Deino A. L., Karner D. B., Owens T. L. and DePaolo D. J. (1998) Intercalibration of standards, absolute ages and uncertainties in ${ }^{40} \mathrm{Ar} /{ }^{39} \mathrm{Ar}$ dating. Chem. Geol. 145, 117-152.

Robinson P., Townsend A. T., Yu Z. and Münker C. (1999) Determination of scandium, yttrium and rare earth elements in rocks by high resolution inductively coupled plasma mass spectrometry. Geostandards Newsletter 23, 31-46.

Ryder G. (2002) Mass flux in the ancient Earth-Moon system and benign implications for the origin of life on Earth. J. Geophys. Res. 107(E4), 6-1-6-14.

Schaeffer O. A., Husain L. and Schaeffer G. A. (1976) Ages of highlands rocks: the chronology of lunar basin formation revisited. Proc. Lunar Sci. Conf. 7th, 2067-2092.

Schaeffer O. A. and Husain L. (1973) Early lunar history: ages of 2 to $4 \mathrm{~mm}$ soil fragments from the lunar highlands. Proc. Lunar Sci. Conf. 4th, 1847-1863.

Schaeffer G. A. and Schaeffer O. A. (1977) ${ }^{39} \mathrm{Ar}-{ }^{40} \mathrm{Ar}$ ages of lunar rocks. Proc. Lunar Sci. Conf. 8th, 2253-2300.

Spudis P. D. (1993) The Geology of Multi-Ring Impact Basins. Cambridge University Press, Melbourne, 263 pp.

Steiger R. H. and Jäger E. (1977) Subcommission of Geochronology: convention on the use of decay constants in geo- and cosmochronology. Earth Planet. Sci. Lett. 36, 359-362.
Stöffler D. and Ryder G. (2001) Stratigraphy and isotope ages of lunar geological units: chronological standard for the inner Solar System. Space Sci. Rev. 96, 9-54.

Stöffler D., Knöll H.-D., Marvin U. B., Simonds C. H. and Warren P. H. (1980) Recommended classification and nomenclature of lunar highlands rocks - a committee report. In Proc. Conf. Lunar Highlands Crust (eds. J. J. Papike and R. B. Merrill). Pergamon Press, New York, pp. 51-70.

Stöffler D., Ostertag R., Reimold W. U., Borchardt R., Malley J. and Rehfeldt A. (1981) Distribution and provenance of lunar highland rock types at North Ray crater, Apollo 16. Proc. Lunar Planet. Sci. Conf. 12B, 185-207.

Stöffler D., Bischoff A., Borchardt R., Burghele A., Deutsch A., Jessberger E. K., Ostertag R., Palme H., Spettel B., Reimold W. U., Wacker K. and Wänke H. (1985) Composition and evolution of the lunar crust in the Descartes Highlands, Apollo 16. Proc. Lunar Planet. Sci. Conf. 15th, J. Geophys. Res. 89, C449-C506.

Turner G. (1968) The distribution of potassium and argon in chondrites. In Origin and Distribution of the Elements (ed. L. H. Ahrens). Pergamon, London, pp. 387-398.

Turner G. and Cadogan P. H. (1975) The history of lunar bombardment inferred from ${ }^{40} \mathrm{Ar}-{ }^{39} \mathrm{Ar}$ dating of highlands rocks. Proc. Lunar Sci. Conf. 6th, 1509-1538.

Ulrich G. E. (1973) A geologic model for North Ray crater and stratigrtaphic implications for the Descartes region. Proc. Lunar Sci. Conf. 4th, 27-39.

$\mathrm{Yu}$ Z., Norman M. and Robinson P. (2003) Major and trace element analysis of silicate rocks by XRF and laser ablation ICPMS using lithium borate fused glasses: matrix effects, instrument response, and results for international reference materials. Geostandards Newsletter 27, 67-89.

Warner J. L., Phinney W. C., Bickel C. E. and Simonds C. H. (1977) Feldspathic granulitic impactites and pre-final bombardment lunar evolution. Proc. Lunar Sci. Conf. 8th, 2051-2056.

Warren P. H. and Kallemeyn G. W. (1984) Pristine rocks (8th foray): "plagiophile" element ratios, crustal genesis, and the bulk composition of the Moon. Proc. Lunar Planet Sci. Conf. 15th, J. Geophys. Res. 89(suppl.), C16-C24.

Warren P. H., Claeys P., and Cedillo-Pardo E. (1996) Mega-impact melt petrology (Chicxulub, Sudbury, and the Moon): effects of scale and other factors on potential for fractional crystallization and development of cumulates. In The Cretaceous-Tertiary Event and Other Catastrophes in Earth History (G. Ryder, D. Fastovsy, and S. Gartner, eds.), 105-124. Geol. Soc. Am. Spec. Paper 307, Boulder CO.

Warren P. H., Taylor D. J., de Leuw S., Cosarinsky M., Schmidt B. E., Dyl K. and Spengler E. (2007) SEM-petrography of ostensibly ancient North Ray crater lunar impact melt rocks. Meteoriti. Planet. Sci 42, A160.

Warren P. H., Taylor G. J., Keil K., Kallemeyn G. W., Rosener P. S. and Wasson J. T. (1983) Sixth foray for pristine nonmare rocks and an assessment of the diversity of lunar anorthosites. Proc. Lunar Planet Sci. Conf. 13th, J. Geophys. Res. 88(suppl.), A615-A630.

York D. (1969) Least squares fitting of a straight line with correlated errors. Earth Planet. Sci. Lett. 5, 320-324.

Associate editor: Randy L. Korotev 